\title{
Producing Normative Knowledge between Salamanca and Michoacán
}

\author{
Alonso de la Vera Cruz and the Bumpy Road of Marriage
}

\author{
José Luis Egío
}

Marriage occupies a prominent place among the topics that can be considered as paradigmatic examples of the way in which normative knowledge was produced within the School of Salamanca and circulated globally during the early modern period. Just as with many other debates concerning the religious and moral instruction of indigenous peoples, the diversity and specificity of marital customs and practices in America and Asia led the most prominent missionaries to reflect on what the guiding principles should be when dealing with local customs concerning marriage and the organisation of the household. The challenge - both theoretical and practical - was enormous. Missionary work required fixed and coherent guidelines in order to make a clear distinction between the concepts, practices, customs, and rites that could be tolerated after the conversion of the pagan inhabitants of both continents to Christianity, and the indigenous traditions that should be eradicated. Then, clever and workable strategies needed to be developed in order to root out unacceptable local traditions, progressively introduce Christian normativity, and replace, little by little, other customs that, even if permissible, were far from desirable.

In this short contribution, I shall not repeat the comprehensive perspectives that experts of marriage in the early modern period - like Ana De Zaballa, Benedetta Albani, Federico Aznar Gil, Daisy Rípodas Ardanaz, or Pilar Latasa $^{1}$ - have written about the way in which Christian marriage was progressively introduced in early modern America and the complex ways in which traditional Christian and European normativity was translated into many distant

1 De Zaballa Beascoechea, "Matrimonio" and "El matrimonio indígena antes y después de Trento"; Albani, Sposarsi nel Nuovo Mondo; Albani, "El matrimonio entre Roma y la Nueva España"; Aznar Gil, La introducción del matrimonio cristiano en Indias, "El matrimonio en Indias: recepción de las Decretales X 4.19.7-8", and "La libertad de los indígenas para contraer matrimonio en las Indias"; Rípodas Ardanaz, El matrimonio en Indias: realidad social y regulación jurídica; Latasa, "Matrimonios clandestinos y matrimonios secretos", “Trent, Marriage 
regions - both geographically and culturally - within the Spanish empire. Marya Camacho's chapter in this book also offers a detailed perspective on the way in which Spanish law and moral-theological normativity were contextualised and applied in the Philippines in the 17th and 18th centuries. ${ }^{2}$ Even if some of the classic literature dedicated to what we could call the globalisation of Christian marriage in the early modern period seems too legalistic and old-fashioned, new methodological perspectives are constantly appearing in a field that is undergoing continuous renewal. ${ }^{3}$

As with many other missionary issues, the sacramental theology elaborated at the University of Salamanca and learnt by the many jurists and theologians, who were trained in the Salmantine studium and deployed to the front lines of conversion in America and Asia, played an important role in the contentious introduction of Christian marriage. While, until now, the focus of many studies has been on purely legal issues such as the writing, overseas introduction, and reception of law and its inevitable adaptation to local circumstances, the resistance it encountered, or the agonistic interaction between different institutions and law-givers, theological speculation has usually been left aside as something that could be dispensed with or that was not significant to understanding the process of globalising Christian marriage. Individual figures such as Dionisio Borobio - without doubt, the greatest contemporary expert on the sacramental theology of the School of Salamanca represent an exception to this. He has investigated the way in which the key authors of the School (Vitoria, Soto, Cano) explained the sacraments from the academic Salmantine sphere, ${ }^{4}$ as well as the enculturation process which allowed the integration of this Salamanca-based sacramental theology into different indigenous cultures in the New World, ${ }^{5}$ especially among the

and Freedom in the Viceroyalty of Peru", and "Tridentine Marriage Ritual in Sixteenth- to Eighteenth Century Peru".

2 Camacho, "Indigenous Marriage in the Philippines in the Light of Law, Legal Opinions, and Moral Cases (17th and 18th centuries)".

3 A good point of reference to new approaches examining the interaction between central, local institutions and the agency of individuals that also demonstrates how complex perspectives on cultural translation of normativities and gender studies are reshaping the way in which the expansion of Christian marriage has historically been explained and understood can be found in the Focus section of Rechtsgeschichte - Legal History Rg 27 (2019), "Global Perspectives on Tridentine Marriage".

4 Borobio, Unción de enfermos, orden y matrimonio en Francisco de Vitoria y Domingo de Soto; Sacramentos en general: bautismo y confirmación en la Escuela de Salamanca: Fco. Vitoria, Melchor Cano, Domingo Soto, and El sacramento de la penitencia en la Escuela de Salamanca: Francisco de Vitoria, Melchor Cano y Domingo de Soto.

5 Borobio, Aznar Gil, García y García, Evangelización en América. 
Nahua. ${ }^{6}$ However, just as legal literature habitually leaves theological speculation aside, important canon-law issues are, in their turn, not sufficiently taken into account in the erudite writings that Borobio dedicated to the cultural translation of Salmantine sacramental theology.

Following the methodological premises outlined by Thomas Duve in the introductory remarks which open this book and, as in the chapters by Natalie Cobo, Osvaldo Moutin, and Marya Camacho, - in which normative statements contained in academic treatises or issued on certain occasions like judgments and opinions are examined in terms of their relationship to the canons promulgated by local church councils, decisions taken by the councils of the Holy Office sitting in different overseas cities of the Spanish empire, or matters of litigation under discussion in many other secular and religious institutions $-{ }^{-7}$ in the following pages, I shall demonstrate how 16 th-century scholastic literature on marriage influenced different legislative processes that took place simultaneously in places as distant as Michoacán, Madrid, and Rome. I shall also examine how, on their own, the authors of theological writings produced in some of the most remote corners of the empire, the lands inhabited by the Purépecha and Chichimeca nations in central-northern Mexico, reflected on and made constant reference to the significant changes introduced into canon law by Roman popes and conciliar sessions held in Trent, and into royal cédulas dictated in Madrid or El Escorial.

Just as the laws regulating wars of conquest, encomiendas, forced indigenous labour, the tributary system, the administration of baptism, and commercial relations between natives and Spaniards, specific matrimonial legislation for the Americas (a significant part of what has been called derecho indiano) resulted from an intense dialogue between jurists and theologians. While other jurists and theologians of the School of Salamanca tried to analyse some of the problematic implications in foris interno et externo of the conquest (Vitoria, Soto), commercial transactions (Tomás de Mercado, Bartolomé de Albornoz), or idolatrous practices (Francisco Suárez, José de Acosta) in the novel context of the Americas, learned men who were directly involved in evangelisation

6 Borobio, Evangelización y sacramentos en la Nueva España (s. XVI) según Jerónimo de Mendieta; Borobio, "Los sacramentos en Bartolomé de Ledesma (1525-1604)".

7 See, in particular, Camacho's chapter, which demonstrates that a renowned and industrious theologian such as Juan de Paz could be considered a kind of oracle in the resolution of many difficult cases. In this sense, it is not by chance, that, as Camacho states, "among those who consulted him were bishops and provincials of other religious orders, corporate bodies such as the cathedral chapter, the Real Audiencia, and the Hermandad de la Misericordia, as well as private individuals". 
paid special attention to questions related to the administration of the sacraments and tried to offer pedagogic syntheses to explain their function and the meaning of the related signs to the natives. In a distant country, different and unforeseen cultural, economic, and social barriers could hinder the proper administration of a certain sacrament: the traditional decision-making role of parents and authorities could obscure the free consent of spouses; shyness and diffidence derived from cultural taboos made the confession of sins, contrition, and absolution impossible in most cases; even a logistical problem such as the absence of vines and olives in most of the American regions affected the administration of the Eucharist and last rites.

In order to deal with these and other kinds of local circumstances, learned men, combining a solid academic background with many years of missionary experience in distant regions of the empire, wrote new cross-cultural manuals for the administration of the sacraments or propaedeutic literature focused on one of them. In some cases, the specificity of this pragmatic literature was such that because often authors did not limit themselves to adapting a pre-existing normativity to the American context but instead elaborated specific literature for every one of the myriad of peoples being converted to Christianity, as happened in most instances - it has made these religious genres key sources in current anthropological, ethnological, and historical research. ${ }^{8}$

One of the most specific treatises - considering both its thematic and geographical scope - that belonged to this wave of early modern pragmatic literature is Alonso de la Vera Cruz's Speculum coniugiorum [Mirror of marriages], dedicated to the sacrament of marriage. Apart from the many matrimonial issues to which the turbulent and problematic 16th-century gave rise in Christian Europe, ${ }^{9}$ Vera Cruz offered answers in this book to many dubia that

8 Speaking in general terms of the growing differentiation which distinguished the extensive epistemic network of the Catholic world from the smaller and more homogeneous Christian orb of late antiquity and the Middle Ages which can be seen clearly in pragmatic normative literature, Thomas Duve stated, "we can observe that, with the nearly contemporary European expansion and the media revolution, a growing variety of epistemic communities produced bodies of normative knowledge, drawing on the existing texts, modifying or interpreting them, often with specific communities of practice in mind. The epistemic network now spanned over larger territories and the variety of situations led to increasing differentiation. Thus, the so-called 'legal pluralism' inherent to medieval and early modern European law became even more complex: the attempt to provide diverse communities of practice with adequate tools for their task accelerated the continuous processes of differentiation within the overlapping normative orders present in the Catholic world", Duve, "Pragmatic Normative Literature and the Production of Normative Knowledge", 6-7.

9 Such as the sacramental character of marriage, the sufficiency of the consent of the spouses for considering a marriage legitimate and indissoluble, clerical celibacy, etc. 
could arise when a young priest or missionary tried to venture into the vast and complex "province" of Indian marital customs, considered to be an authentic "labyrinth of Daedalus" by Francisco Cervantes de Salazar, ${ }^{10}$ professor of rhetoric and colleague of Vera Cruz at the recently created University of Mexico, where the Augustinian friar held the prestigious chair of Saint Thomas." ${ }^{11}$ The prefatory letter - which was written by another of these colleagues, Juan Nigret, who simultaneously held the offices of rector of the university and archdeacon of the cathedral in 1556 when the book was first printed in Mexico City - indicated that, given the complexity of this theological and legal field, the cathedral chapter also received, with interest and satisfaction, such a practical treatise which intended to "extirpate all the scruples and ambiguities" that had prevailed until then in the matter of Indian marriages. ${ }^{12}$ Given that Virginia Aspe and Dolors Folch have already introduced the figure of Alonso de la Vera Cruz in their contributions to this book, offering detailed assessments of his education at Alcalá and Salamanca and addressing most of the extensive list of topics that interested the Augustinian friar (from logic to cosmography, as well as the most burning political debates of his time), I shall analyse the juridical issues he examined in Speculum coniugiorum directly.

A recent approach to these epochal debates can be found in Reynolds, How Marriage Became one of the Sacraments.

10 See the suggestive laudatory letter with which Francisco Cervantes de Salazar recommended the Speculum coniugiorum, highlighting its value as a guide and practical tool "Quae tu damna candide lector, nisi oscitas, \& stertis, hoc uno libro comparato, tam facile vitabis ut in re difusißima, \& labirintho Dedali implicatori tutius, ac certius quam Theseus, provintiam matrimonialem (perpaucis quidem obviam) \& adire \& superare poteris Cuius laboris compendium", Francisco Cervantes de Salazar, "Franciscus Cervantes Salazarus artium magister, iuris pontificei \& sacrae Theologiae Candidatus in academia Mexicana Rhetoricae professor: candido lectori. S.", in Vera Cruz, Speculum coniugiorum (1556), 6-7.

11 On the hesitant and tortuous beginnings of the faculty of theology of the University of Mexico and the conflicts between the Dominican and Augustinian orders for the provision of the first chairs, see Ramírez González, Grupos de poder clerical en las Universidades hispánicas, Vol. II, 79-80 and Pavón Romero, Ramírez González, "La carrera universitaria en el siglo XVI", 59-66. The most detailed account of Vera Cruz's brief career at the university can be found in Pavón Romero, "La Universidad de México en tiempos de fray Alonso de la Veracruz".

12 "Verum quid opus est verbis? Nihil in libro non invenitur ad Indorum nodos scindendos, ad coniugis, \& viri ligamen firmandum, ad omnium tandem scrupulum, vel ambiguitatem extirpandam hic liber conducit. Gratulent igitur omnes pro viribus Illephonso (est quidem Augustinorum decus) propter aureum emissum opus", Juan Nigret, "Ioannis Nigret in Artibus et Theologia magister, \& in metropoli Mexicana Archidiaconus, \& universitatis rector, Illephonso religiosissimo, sapientissimoque magistro. S.", in Vera Cruz, Speculum coniugiorum (1556), 4-5. 
Vera Cruz's matrimonial treatise was first published in Mexico City in $155^{6,13}$ and was in fact one of the first books printed in America - the first printing press in Mexico City was established in 1539 (figure 10.1). During his lifetime, the Augustinian friar prepared two corrected and elaborated editions of the Speculum: the 1562 Salamanca edition ${ }^{14}$ and the 1572 Alcalá edition, ${ }^{15}$ which Vera Cruz worked on during the long period he was forced to remain in Castile in order to defend himself against the accusations of heresy that had been made against him by the archbishop of Mexico, Alonso de Montúfar, and to fight for the privileges of his order, which were being threatened by the same archbishop..$^{16}$ Although the Salamanca edition did not introduce substantial changes to the Mexican princeps, the 1572 version of the treatise was systematically revised to adapt to the recently concluded Council of Trent (figure 10.2). Apart from the many additions that can be seen in this third edition of the Speculum, Vera Cruz also wrote his Appendix ad Speculum coniugiorum to lay out his ideas on "clandestine marriage" with positions "defined in the holy and universal Council of Trent" and, above all, to explain and justify some of the positions that, being appropriate for the missionary context of the Indies, might have seemed strange and unorthodox for European readers. The Appendix was printed separately in Alcalá in $1571,{ }^{17}$

13 Vera Cruz wrote the book during the period he temporarily abandoned the missions of Michoacán and Atotonilco (in the modern-day state of Hidalgo) where he had lived for almost 20 years and moved to Mexico, where he held a chair at the faculty of theology of the recently created University of Mexico from 1554. Vera Cruz, Speculum coniugiorum aeditum per R. P. F. Illephonsum a Vera Cruce Instituti Haeremitarum Sancti Augustini, artium ac sacrae Theologiae doctorem, cathedraeque primariae in inclyta Mexicana academia moderatorem, México, Juan Pablo Bricense, 1556.

14 Vera Cruz, Speculum coniugiorum ad modum R. P. F. Illephonsi a Vera Cruce Sacri ordinis Eremitarum. S. Augustini, bonarum artium, ac sacrae Theologiae Magistri, moderatorisque; Cathedrae Primariae in Universitate Mexicana in partibus Indiarum maris Oceani: \& Provincialis eiusdem ordinis, \& observantiae. Nunc secundo opus elaboratum, \& ab authore a plurimis mendis, quibus scatebat, limatum, \& in multis locis auctum, Salamanca, Andrea de Portonaris, 1562.

15 Vera Cruz, Speculum coniugiorum ad modum R. P.F. Illephonsi a Vera Cruce Sacri ordinis Eremitarum. S. August. bonarum artium, ac sacrae Theologiae Magistri, moderatorisque; cathedrae primariae in universitate Mexicana in partibus Indiarum maris Oceani: olim ibi Provincialis eiusdem ordinis, nunc Prioris sancti Philippi apud Madritum Carpentanorum. Nunc tertio opus elaboratum, ab authore a plurimis mendis, quibus scatebat, limatum, \& in multis locis auctum, \& iuxta diffinita \& declarata in sacro concilio Tridentino, per modum appendicis in fine scitu digna multa disputata, Alcalá, Juan Gracián, 1572.

16 See Lazcano, Fray Alonso de Veracruz (1507-1584), 73-88.

17 Vera Cruz, Appendix ad Speculum coniugiorum [...]. Iuxta diffinita in sacro universali Concilio Tridentino, circa matrimonia clandestina, Alcalá, Pierre Cosin, 1571. 
but incorporated into and bound together with the revised edition of the Speculum, as is attested by most of the surviving copies of both materials. ${ }^{18}$ A final 16th-century edition of the Speculum, also accompanied by the postTridentine Appendix, was printed in Milan in $1599,{ }^{19} 15$ years after Vera Cruz's death. It was not directly supervised by his author and did not introduce changes to the content of the Alcalá edition. Nevertheless, this Milan edition is extremely important because it shows the circulation of Vera Cruz's doctrines on marriage beyond the Spanish realm, making it an important example of the bidirectional way in which ideas circulated between Europe and America in the early modern period. It allows us to demonstrate that while on the one hand, legal provisions and normativity issued in the Italian peninsula by the highest authorities of the Catholic world - the pope and the council greatly altered the daily routine of missionaries working thousands of kilometres away, on the other, some of these humble missionaries managed to make their voice heard in that very country, the centre of the Christian world, and could, in turn - with their bizarre accounts of Purépecha and Nahua matrimonial customs - influence both local practices and decisions in dioceses quite close to Rome.

Dedicated to many specific and erudite theological and canon-law issues related to marriage, Vera Cruz's long treatise is an exceptional viewpoint from which to draw tentative answers to some of the complex methodological and historiographical questions raised by Thomas Duve in his introductory chapter. Attentively following the intricate argumentation of the Speculum coniugiorum, some partial but still relevant responses can be given to questions such as: who should be considered as a member of this School of Salamanca as constructed by a nationalistic historiography in the late

18 During a research trip in Michoacán in which I gathered some materials to write this chapter, I consulted various copies of the 1572 edition: 1) Fondo Antiguo de la Universidad Michoacana (FAUM) (вPUм BT2O V4 1572), which once belonged to the Seminario Tridentino de Valladolid de Michoacán (now, Morelia); 2) Museo Regional Michoacano (56950-11), which originally belonged to the Augustinian monastery of Cuitzeo (see figure 10.2) and which Vera Cruz himself had established in the second period in which he occupied the post of provincial of the Augustinians of Mexico (1548-1551); 3) Museo de Sitio Casa de Morelos (MSCM) (56941-2), with an ex libris from the Monastery of Tiripetío, the first Augustinian monastery in Michoacán, where Alonso de la Vera Cruz taught arts and theology after his arrival in Mexico. All the copies of the 1572 edition of the Speculum consulted were bound together with the 1571 Appendix.

19 Vera Cruz, Rev. Patris Fr. Alphonsi a Vera Cruce Hispani Ordinis Eremitarum S. Augustini. Et in primaria cathedra mexicana universitatis $S$. Theologiae Doctoris. Speculum coniugiorum cum appendice. Nunc primum in Italia Typis excusum, Milano, Pacifico Ponti, 1599. 


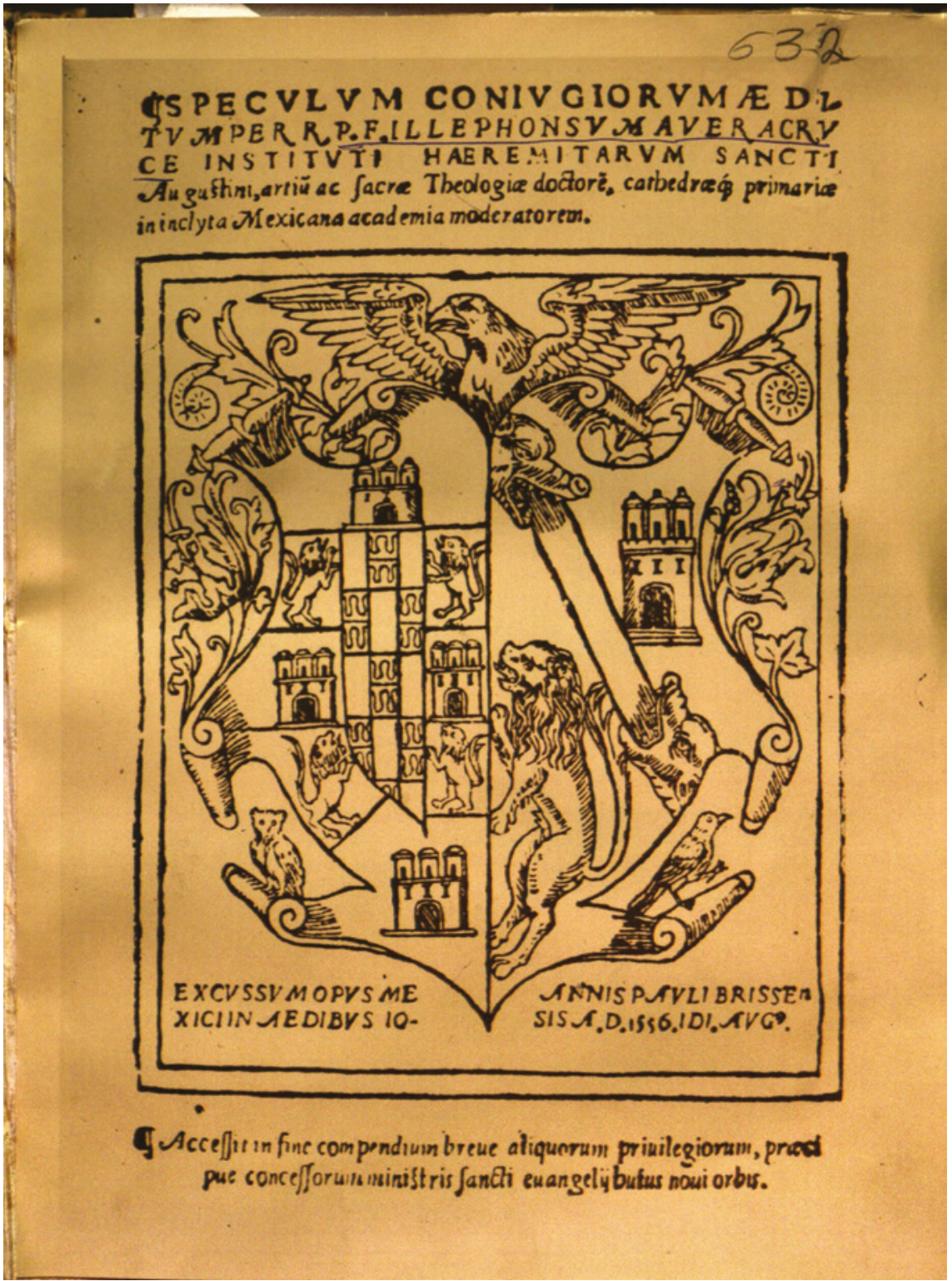

FIGURE 10.1 Alonso de la Vera Cruz, Speculum coniugiorum, México 1556: Juan Pablo Bricense (Biblioteca Pública de la Universidad Michoacana, в PUм K623 V4 1566) 


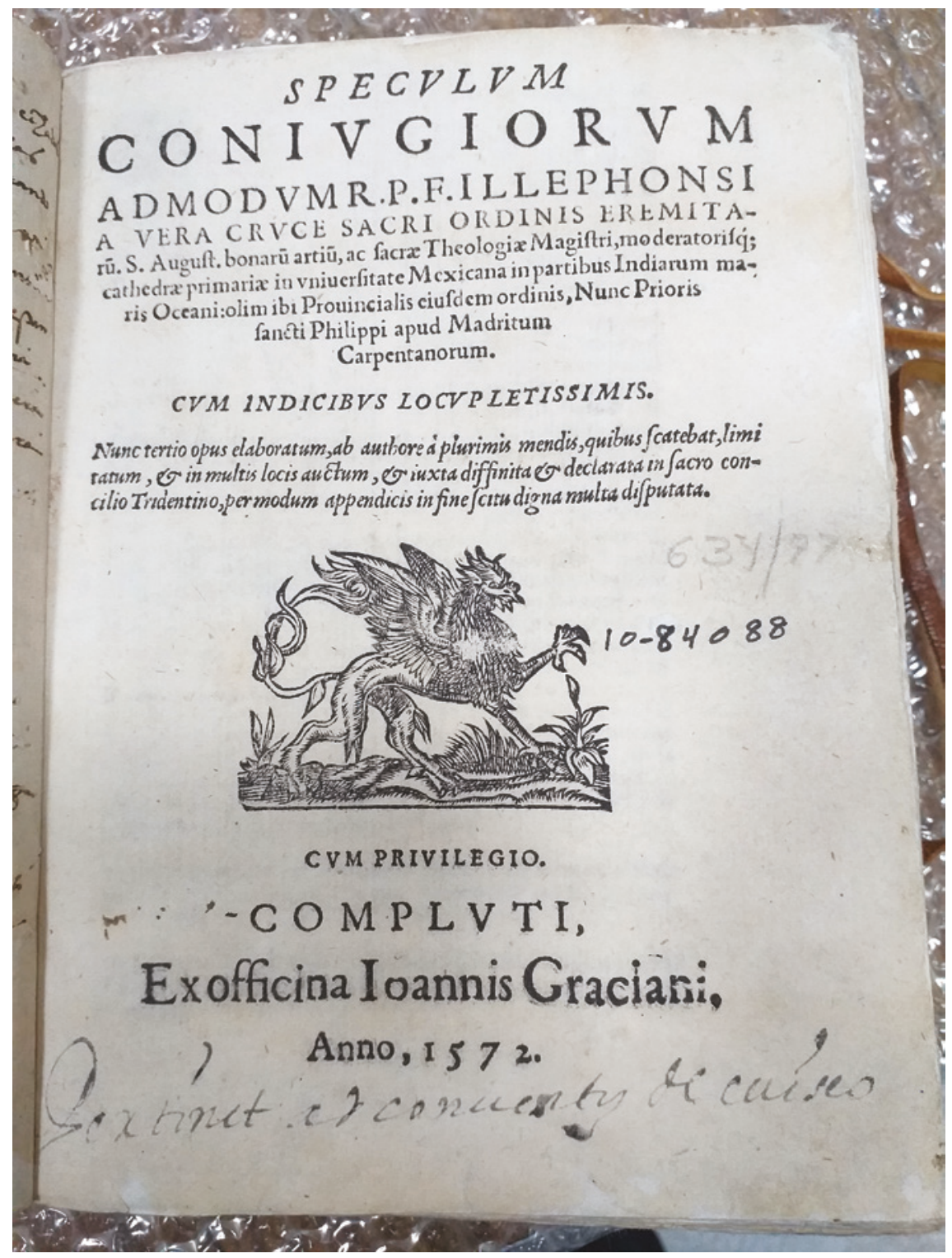

FIGURE 10.2 Alonso de la Vera Cruz, Speculum coniugiorum, Alcalá 1572: Juan Gracián (Museo Regional Michoacano, 56950-11) 
19th century? What was the concrete role of Vitoria, traditionally identified as founder of the School and leading figure in the creation of the conceptual framework used by later theologians and jurists ascribing to the School? What importance should be given to the authors who preceded Vitoria at the University of Salamanca? ${ }^{20}$ What was the relationship between the Salamanca masters and the great exponents of early modern European scholasticism (Cajetan, Catarino, etc.)? Did they all belong to the same intellectual movement, or are there any noticeable features distinguishing scholastic production, particularly that of Iberian or specifically Spanish origin? How did these early modern masters interpret and make use of medieval scholasticism in the 16th century? Can they be considered mere epigones of the dark Middle Ages, devoid of any originality as Alzate, Díaz de Gamarra, Moreno Escandón, and other American intellectuals of the Enlightenment claimed in their satirical writings against the "inútil jerigonza"21 [useless gibberish] of the Aristotelian-Thomist Spanish tradition? Conversely, is there something innovative, "modern", and worthy of interest in the Salamanca masters and their American disciples? What kind of special features distinguished American scholasticism, and to what extent can we consider figures such as Alonso de la Vera Cruz, writing thousands of kilometres away from Salamanca, as full members of that School? In order to give at least some kind of tentative answers to these general and complex questions - which really form part of an entire research programme -, it is especially important to focus on some of the topics covered by Thomas Duve in the opening chapter, points on which these research questions converge: the scholastic methods employed within the School of Salamanca to produce normative knowledge, the academic practices shared by European and American masters forming part of the School, and the common patrimony of auctoritates that they all read, commented on, and invoked - elements that allow us to conceptualise the School "as an epistemic community and a community of practice", while, at the same time, placing "authors and texts in meaningful relation to each other, irrespective of whether they had been in direct contact". ${ }^{22}$

$20 \quad$ Another important topic extensively examined by Virginia Aspe in her contribution to this book where she describes figures such as Alonso Fernández de Madrigal, known as "El Tostado".

21 Torchia Estrada, "La querella de la escolástica hispanoamericana", 38.

22 See Duve, "The School of Salamanca. A Case of Global Knowledge Production". 


\section{"Viviendo así empapelada su memoria": Vera Cruz's Books and Marginalia, "Point Zero" of a Process of Global Knowledge Production}

As Duve stated in the methodological premises which serve as a guiding thread for this book, within the general process of normative knowledge production by Salamanca scholars, the rigorous selection and compilation of the relevant auctoritates were especially important because they were the starting point for the elaboration of their own arguments. Compared with most scholastics of his time, the case of Vera Cruz can be considered especially enlightening for the academic interested in knowing more about this first step of the early modern ars inveniendi. Not only are his reports and treatises very illustrative, given the great number of sources he used and the careful way in which legal and theological compilations and writings of previous scholars were quoted, but also the libraries where he wrote them and the books he personally read and annotated during his writing process are still partially accessible today. Unlike the books which Vitoria, Soto, and Cano used during their lifetime and that might have been held in the libraries of Salamanca, which were heavily damaged during the French invasion of 1808-1813 and in other times, some of these collections that belonged to the extensive network of Augustinians monasteries founded by Vera Cruz have survived to the present day. ${ }^{23}$

In Michoacán, the region where Vera Cruz spent most of his life, an invaluable cultural patrimony has been preserved in the form of books which once belonged to Tiripetío (the monastery in which Vera Cruz lived and taught for many years from 1536 onwards), Tacámbaro, Cuitzeo, Yuririhapúndaro, and other monasteries which, after being established by Vera Cruz during his first provincialate (1548-1551), were the occasional residences and working environments of their founder. Surviving plagues, natural disasters, excessive humidity, secularisation, wars, and revolutions, some books belonging to magister Vera Cruz - in fact, the first European books used as teaching tools in continental America - were rediscovered in a humid and sealed room of the monastery of Cuitzeo in $1932-1933 .{ }^{24}$ Thanks to the intervention and financial support of the unforgotten socialist president Lázaro Cárdenas, who was

23 Vera Cruz was provincial of the Augustinians of Mexico five times from 1548 to 1578, a period in which he promoted the foundation of at least 29 monasteries, most of them in modern-day Michoacán, but also in regions such as Jalisco, Guanajuato, Zacatecas, Hidalgo, Oaxaca, Veracruz, and Guerrero, Rubial García, "Fray Alonso de la Veracruz, agustino", 83-84.

Fernández de Córdoba, "Sumaria relación de las bibliotecas de Michoacán", 134-135. 
governor of Michoacán at the time, the books were preserved and brought initially to the Museo Regional de Michoacán (Morelia), as the typewritten cards inserted in some of the tomes attest (figure 10.3), ${ }^{25}$ and later stored in the Archivo Histórico Casa de Morelos (Morelia).

In the wake of the great expectations which followed the discovery of the books, a few of them were restored and exhibited at the Museo Regional de Michoacán. Most of them, partially deteriorated over time, were then redeposited in storage and forgotten. Following some decades of institutional neglect, which greatly contributed to the damage of some of the books and which was taken advantage of by thieves who continued to plunder the regional treasures - a practice started in the 18 th century ${ }^{26}$-, the Instituto Nacional de Antropología e Historia (INAH) was finally able to make substantial advances in restoring the entire monasterial collection, consisting of 1,527 books. $^{27}$ To date, approximately 20 per cent of these books have been restored. ${ }^{28}$

25 A typewritten card inserted in a volume in which the three parts of Vera Cruz's course of arts (printed in Salamanca by Juan Bautista de Terranova, 1572-1573) are bound together (Museo Regional de Michoacán (MRM), 57272-333, 57273-334, 57274-335) states "El C. Gral. Lazaro Cárdenas, gobernador del Estado, a petición mía, rescató del abandono en que se encontraban los antiguos libros del convento agustino de Cuitzeo, entre los que se encontraban los de Fray. Alonso de la Veracruz muy posiblemente usados como libros de texto en la Escuela de Altos Estudios, pues hay los que dicen: "Pertinet Tiripetío"'. The cards were probably the doing of Narciso Bassols or Gustavo Corona. Bassols, Minister of Education in 1932, asked the Mexican government to catalogue the collection and provide suitable storage for the books at the Archivo Histórico Casa de Morelos in Morelia, where most of them remain today. Corona, rector of the Universidad Michoacana at the time, decided to transfer the university rectory to the Museo Regional Michoacano in the period 1933-1939. He was leading the institution when the books were discovered. That period is considered as an interval of institutional fusion between the university and the museum by the regional historiography. Nicolás León, predecessor of Corona, and Antonio Arriaga, his successor, both of them famous bibliophiles, directed the museum during long terms of office in which the institution was administered with much more autonomy. See Dávila, Ettinger and García Espinosa (eds.), Patrimonio de la Universidad Michoacana, 87 .

26 It is indeed unfortunate that many of these books, stolen or bought at ridiculous prices, are now kept in university libraries and private collections in the USA, most of them not even accessible to Mexican scholars and students who are blocked by discriminatory barriers to travel and migration.

27 https://www.adabi.org.mx/index.php/descubridor Last consulted 15 May 2020.

28 https://inah.gob.mx/boletines/7789-realizan-trabajos-de-conservacion-del-fondomonasteryual-del-museo-y-archivo-historico-casa-de-morelos Last consulted 15 May 2020 . 

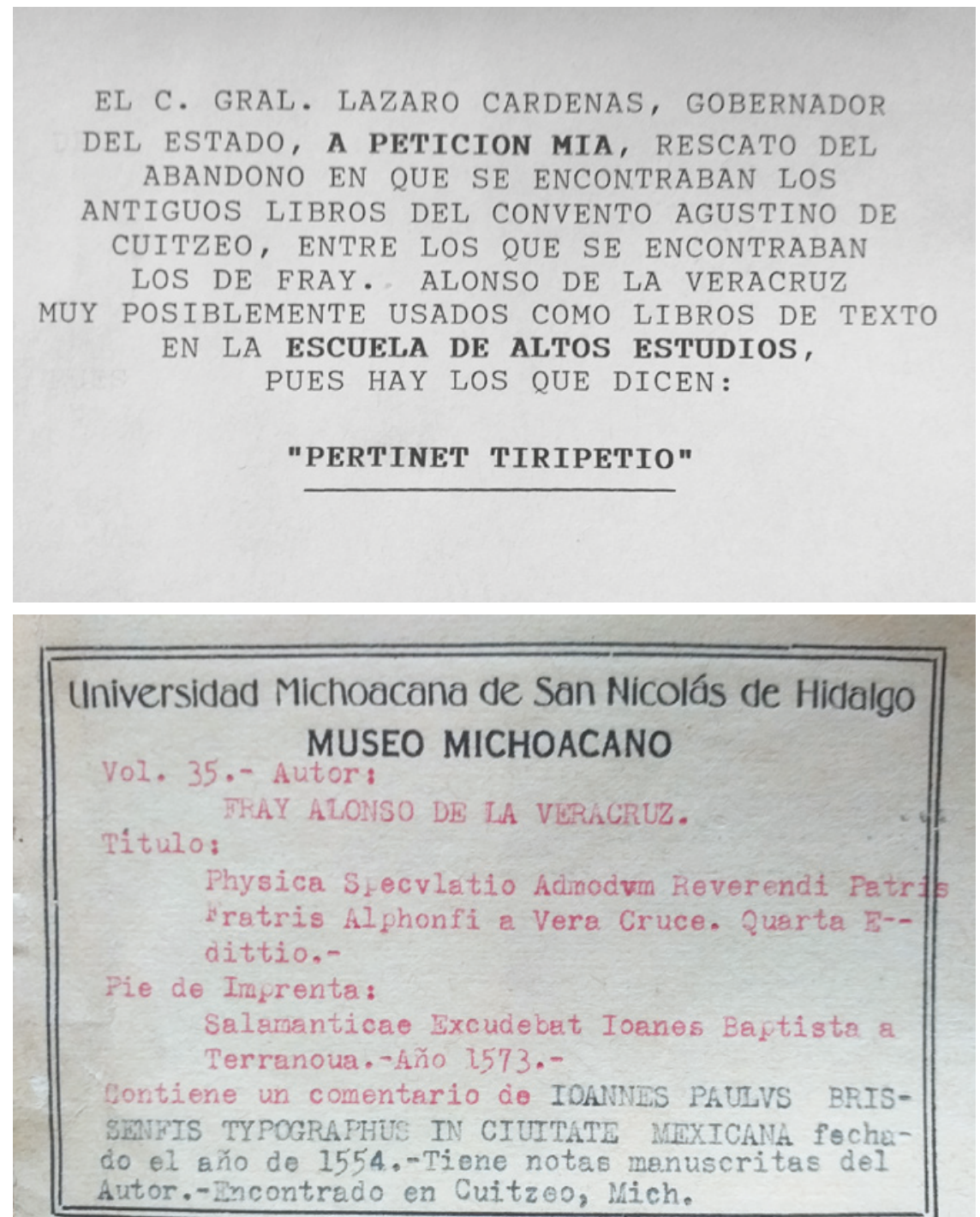

FIGU RE 10.3 Narciso Bassols?, Gustavo Corona?, Typewritten cards inserted in Alonso de la Vera Cruz, Cursus artium, Salamanca 1572-73: Juan Bautista de Terranova (Museo Regional Michoacano, 57272-333, 57273-334, 57274-335)

An examination of some of these restored books enabled me to demonstrate that the vague information and speculation about the famous books of Alonso de la Vera Cruz, which can be found in the existing literature inspired by comments made by the $17^{\text {th }}$ and 18th century chroniclers of the Augustinian order 
in Mexico and Michoacán, are true. ${ }^{29}$ In his Crónica de la orden de N.P. S. Agustín en las provincias de Nueva España (1624), the oldest chronicle of the Mexican Augustinians, Juan de Grijalva had already highlighted the importance that Vera Cruz gave to books and libraries, which were established in most of the monasteries that he personally instituted in the region of Michoacán. Grijalva testified not only that Vera Cruz bought large numbers of books and organised well-equipped libraries in various monasteries, something also attested to by contemporary historiography, ${ }^{30}$ but that he was also an obsessive hoarder, compulsive reader, and punctilious annotator of books.

En la libreria del Collegio de S. Pablo puso sesenta cajones de libros: y no le es inferior la del convento de nuestro Padre San Augustin de Mexico. En el convento de nuestro Padre San Augustin de Tiripitio de Mechoacan ay otra muy buena que el Padre Maestro puso: no lo tenga à encarecimiento el que lo leyere, porque escribimos lo que todos hemos visto, ningún libro ay en S. Pablo, ni en Tiripitio, que no este rayado y margenado, desde la primera hoja hasta la ultima de su letra: y la mayor parte de la libreria de S. Augustin tiene estas notas, en todas las facultades. ${ }^{31}$

Writing about the same topic 20 years later in his chronicle of the Michoacán Augustinians (1644), Diego de Basalenque offered further details about a similar library installed by Vera Cruz in Tacámbaro, which was even bigger than the one previously created at Tiripetío and full of volumes annotated by Vera Cruz. Interestingly, his disciples and later Augustinian fellows kept these books as precious reminders of Vera Cruz's stay at Tacámbaro in $1545^{-1546 . ~}$

29 "Hay otras bibliotecas universitarias que cuentan con secciones pequeñas de historia, como la del Museo Michoacano, que conserva, además, algunas joyas bibliográficas procedentes de la biblioteca del colegio de Tiripetío, anotadas por fray Alonso de la Veracruz", Fernández de Córdoba, "Michoacán: la historia y sus instrumentos", 140.

30 González González and Gutiérrez recently discovered the letters and request orders Vera Cruz addressed to Plantin and other important booksellers of his time, buying 60 boxes of books, which cost 7,ooo ducados, before his second journey to Mexico in 1573. Those books were installed in the library of the Augustinian college of San Pablo in Mexico City. See González González and Gutiérrez, "Los catedráticos novohispanos y sus libros", 89. Various cédulas attest to Vera Cruz's conscientious preparations for this last journey to Mexico, carefully selecting the books and men he would take to the New World, Real cédula de 23-12-1572, Archivo General de Indias, Seville (AGI), Indiferente, 1968, L.19, fol. 63; Real cédula de 19-01-1573, AGI, Indiferente, 1968, L.19, fol. 71v.; Real cédula de 03-O21573, AGI, Indiferente, 1968, L.19, fol. $76 \mathrm{v}$.

Grijalva, Crónica de la orden de N. P. S. Agustín en las provincias de Nueva España, fol. 188r. 
Trajo una muy linda Libreria, mejor, y mas copiosa, que la que puso en Tiripetio, (bien que esta se ha conservado mejor por estar en tierra fría, y estotra en tierra humeda y caliente, donde hierbe la polilla). Estas Librerias nos sirven de tierna memoria, porque todos los libros nos recuerdan la de N. P. pues apenas se hojea uno, que no esté margenado de su letra, con que combida à que los estimemos, y muy à menudo se hagan recuerdos de su dueño. ${ }^{32}$

At the turn of the 17th century, Vera Cruz's annotated books were cherished as "relics". Awareness of the value of this patrimony brought special measures to protect Tacámbaro's library from humidity and moths - perceptible in the remnants which have survived to the present day. According to the Baroque Augustinian chronicler Matías de Escobar (1748), Vera Cruz's books were then transported from tierra caliente to the highlands of Guadalajara and preserved at another college of the order.

Fuese N. V. Maestro por desgracia de Tacámbaro, pero porque se viese lo que estimaba a aquel convento, dejó en él una copiosa librería que había traído cuando vino a leer a este convento, lo considero palacio de Ptolomeo, adonde N. V. Mro. congregó todos los libros de este mundo, tan copiosa era la librería mejor y mayor que había llevado a Tiripitío, estos libros cuando se abrían se veían todos margenados de letra de $\mathrm{N}$. V. Mro.; experimentóse en Tacámbaro por ser el temperamento húmedo y caliente, que la polilla iba a gran prisa deshaciéndonos aquellas dulces memorias de N. Veracruz, y para obviar este daño, ordenó acertado y prudente N. P. lector y provincial Fr. Diego de la Cruz, se trasladasen aquellos cuerpos, reliquias de N. P. Mro. al colegio que su reverencia en Guadalajara crió, a donde con el continuo trasiego de los lectores y estudiantes aplicados sirviesen los repetidos ojeos de bálsamo, que conservasen en los libros recuerdos de N. V. P. Mtro., viviendo así empapelada su memoria. ${ }^{33}$

All these snippets from various Augustinian chroniclers attracted my attention some years ago and led me to think of Vera Cruz as a special case, someone whose marginalia could be an interesting focus of study in terms of the way in which books were written and read in the early modern period. This line of study is still in its infancy in the case of jurists and theologians of the School

32 Basalenque, Historia de la Provincia de San Nicolás Tolentino de Michoacán, fol. 35r. 
of Salamanca. The patrimonial destruction mentioned above seems to have discouraged most historians. Nevertheless, over the past few years, the annotations in the margins of texts by important jurists such as Diego de Covarrubias have started to be studied. ${ }^{34}$ For the purposes of this chapter, when one takes into account - as Duve highlights in his methodological remarks - that the selection of the relevant auctoritates was the step with which every scholastic author initiated his own contribution to a complex process of knowledge production of a collective nature, the quantity, quality, and variety of the marginalia written by Alonso de la Vera Cruz in the books he read and used as authorities make his case quite illustrative of what Duve calls the ars inveniendi of the School of Salamanca.

Given that Vera Cruz was the first master of arts and theology in continental America and the "intellectual" who established the first libraries on the continent, his annotations allow us to travel to the very "point zero" of a process of global knowledge production. For the first time in history, the methods of Salamanca were culturally translated into the local realities of America along with a normativity that had been created and reframed over centuries, something the late-medieval Salmantine masters had considered to be the canon of relevant auctoritates in legal and theological knowledge.

Even if the books from the monasterial collection of Michoacán passed from hand to hand and were annotated by various generations of friars, which makes it very difficult to determine who read and annotated this or that book with precision, a comparison of the marginal notes of some of these books with the manuscript versions of Vera Cruz's Relectio de dominio infidelium, ${ }^{35}$ Compendium generale privilegiorum pro novo orbe indico, ${ }^{36}$ and other documents written and signed by him that have been preserved in various archives, ${ }^{37}$

34 Codoñer Merino and Signes Codoñer, "Una red de lecturas: las anotaciones marginales de Diego de Covarrubias". Lilao Franca noted a similar compulsive tendency to compile, read, and annotate books with extensive marginalia in Diego de Covarrubias, "A la búsqueda de los libros de Diego de Covarrubias", 133 .

35 Edited by Ernest Burrus in a facsimile edition, The writings of Alonso de la Vera Cruz. Defense of the Indians: their rights II. Photographic reproduction and index.

36 Providence, Rhode Island (USA), John Carter Brown Library (JCBL), Ms Codex Lat 4. A manuscript that, as the Latin philologist Joaquín Sánchez Gázquez proved, was written by the scribe to whom Vera Cruz dictated it. Sánchez also demonstrated that the calligraphy of the annotations and corrections introduced into this manuscript by a second hand coincided with that of Vera Cruz. Sánchez Gázquez, "Fray Alonso de la Veracruz (1507-1584) y su Compendium privilegiorum: estado de la cuestión manuscrita”, 374-376.

37 Dolors Folch referred to the letters of Martín de Rada to Alonso de la Vera Cruz in her chapter. These letters are part of a larger collection of letters, reports, and drafts written by Vera Cruz or related to him, Paris, Bibliothèque Nationale de France, Fonds espagnol, 
allows us to ascertain which annotations could be Vera Cruz's handiwork with a certain degree of accuracy.

In some cases, the guardian of the library of the monastery where Vera Cruz consulted and annotated a certain book even indicated that the book "habet ad usum alonso a vera cruce" [Alonso de la Vera Cruz has for use], as is the case in a copy of the Paris 1518 edition of Hadrianus Florentius's ${ }^{38}$ Quaestiones in quartum sententiarum praesertim circa Sacramenta ${ }^{39}$ (figure 10.4). Confirming the remarks of the Augustinian chroniclers, the text is underlined and annotated almost from the first page to the last (figure 10.5). A careful look at the kinds of passages Vera Cruz underlined and annotated in the margins makes it clear that, contrary to the handwritten notes found in academic books used by scholars writing in the contemporary Europe ${ }^{40}$ with his long marginalia, Vera Cruz tried, above all, to highlight and summarise the sections and paragraphs of particular relevance to the missionary context. The aim of the Augustinian friar was also to elucidate for his students and fellow missionaries the way in which a particular fragment - expressing a certain norm and written, in most cases, by well-known auctoritates of an epoch when America did not yet "exist" - could be accommodated to a context totally unforeseen by any authority. Therefore his compulsion to underline and annotate responded to the kind of careful selection of sources which, as Duve notes, distinguished the first step of the scholastic method of knowledge production, as well as to the specific

325. Some of these valuable documents were edited by Burrus, The Writings of Alonso de la Vera Cruz. Spanish Writings I. Sermons, Counsels, Letters and Reports; The writings of Alonso de la Vera Cruz. Spanish writings II. Letters and Reports.

38 Theologian, canon lawyer, and preceptor of Charles $\mathrm{v}$, he became pope under the name of Adrianus vi from 1522 to 1523 .

39 Hadrianus Florentius, Quaestiones in quartum sententiarum praesertim circa Sacramenta, Paris, heirs of Josse Bade, 1518. The copy annotated by Vera Cruz is preserved at the MRM, 56948-9. The Quaestiones in quartum sententiarum are bound together with another book of Hadrianus, Quotlibeticae quaestiones lucubratione exactissima et linceo visu nuper recognitae, Paris, Jean Petit, 1527. This book was also profusely underlined and annotated by Vera Cruz.

40 Such as Covarrubias, whose marginalia were mostly references to other books and passages dealing with the same issue and opened, in this sense, "un abanico de posibilidades para la reconstrucción de su biblioteca o, al menos, de sus lecturas, ya que, en muchos casos, las apostillas son referencias a otros autores que tratan el tema, frecuentemente introducidos por un legito", Lilao Franca, "A la búsqueda de los libros de Diego de Covarrubias", 142. Other annotations in the margins served merely to highlight passages that were of special interest to Covarrubias (making future consultation easy) or contained erudite philological disquisitions. See Codoñer Merino and Signes Codoñer, "Una red de lecturas: las anotaciones marginales de Diego de Covarrubias", 153-180. 
need to adapt the European books of the Augustinian libraries recently created in Michoacán to make them more useful for the concrete challenges the friars would find in the missionary context.

Among the most difficult tasks for recently arrived friars who had no experience of native customs was how to explain the nature of the sacraments and the intrinsic logic of the many subtleties related to their administration with rational arguments in a way that was comprehensible to the Nahua and Purépecha infidels and neophytes. For example, in one of his many annotations to Hadrianus Florentius's exposition on baptism (figure 10.6), Vera Cruz was concerned with one of the most heart-rending issues that could arise in a missionary context in places where the parish centre was located many kilometres from isolated doctrinas and indigenous villages: namely, what to do with the dying or dead children that parents brought to the monasteries to have baptised and how to explain the eternal destiny of these children's souls to the parents. Could the parents' profession of faith be considered sufficient for the salvation of their children? Although painful, Vera Cruz shared Hadrianus' view, ${ }^{41}$ profusely underlined in his copy and summarised in the margins,

That the children would be saved when they are brought, dying before being baptized is something that, being possible for God, is not certain. He considers that the faith of the parents alone was not enough in natural

41 "Ad tertium quo ad materiam dicit magister di.quarta parti. Parvulis non sufficit fides ecclesiae sine sacramento, qui si absque baptismo fuerint defuncti etiam cum ad baptismum deferuntur damnabuntur, ut dicit multis sanctorum testimoniis approbari. Dicunt tamen quidam pie credi quod deus sua benignitate ibi suppleret quando deesset ex parte sacramenti quod utique certum est deum posse cum virtutem suam non alligaverit sacramentis: sed quod sic faciat nulla est certitudo: quia si non facit: non iniuste facit: cum nullus sit debitor nisi ex promisso: et istud non promissit. Et ad primam probationem dico: quod non suffecit tempore legis nature parvulis sola fides interior parentibus: sed sub protestatione exteriori que habebat vim sacramenti, unde verbum Greg.de conse.dist.iiii [...]. Si inferatur: ergo saltem fides protestata adhuc sufficiet pro parvulis ad salute, non valet consequentia: quia tunc materia sacramenti contra originale erat indifferenter quaelibet fidei protestatio quae ut dicit Hugo de sancto Victore celebrabatur voluntate non necessitate: scilicet sub determinato modo. Pro tempore vero legis novae materia illius sacramenti est determinate: puta aqua et determinate eius forma [...]. Potuit tamen eis deus suam gratiam conferendo originale remittere, cum virtutem suam nequaquam alligaverit sacramentis et fecisse pie credi potest: sed non temere asseri quod certitudinem ex scriptura et doctrina ecclesiae non habet", Hadrianus Florentius, Quaestiones in quartum sententiarum praesertim circa Sacramenta, fol. XIVr, MRM, 56948-9. Underlining added by Vera Cruz. 


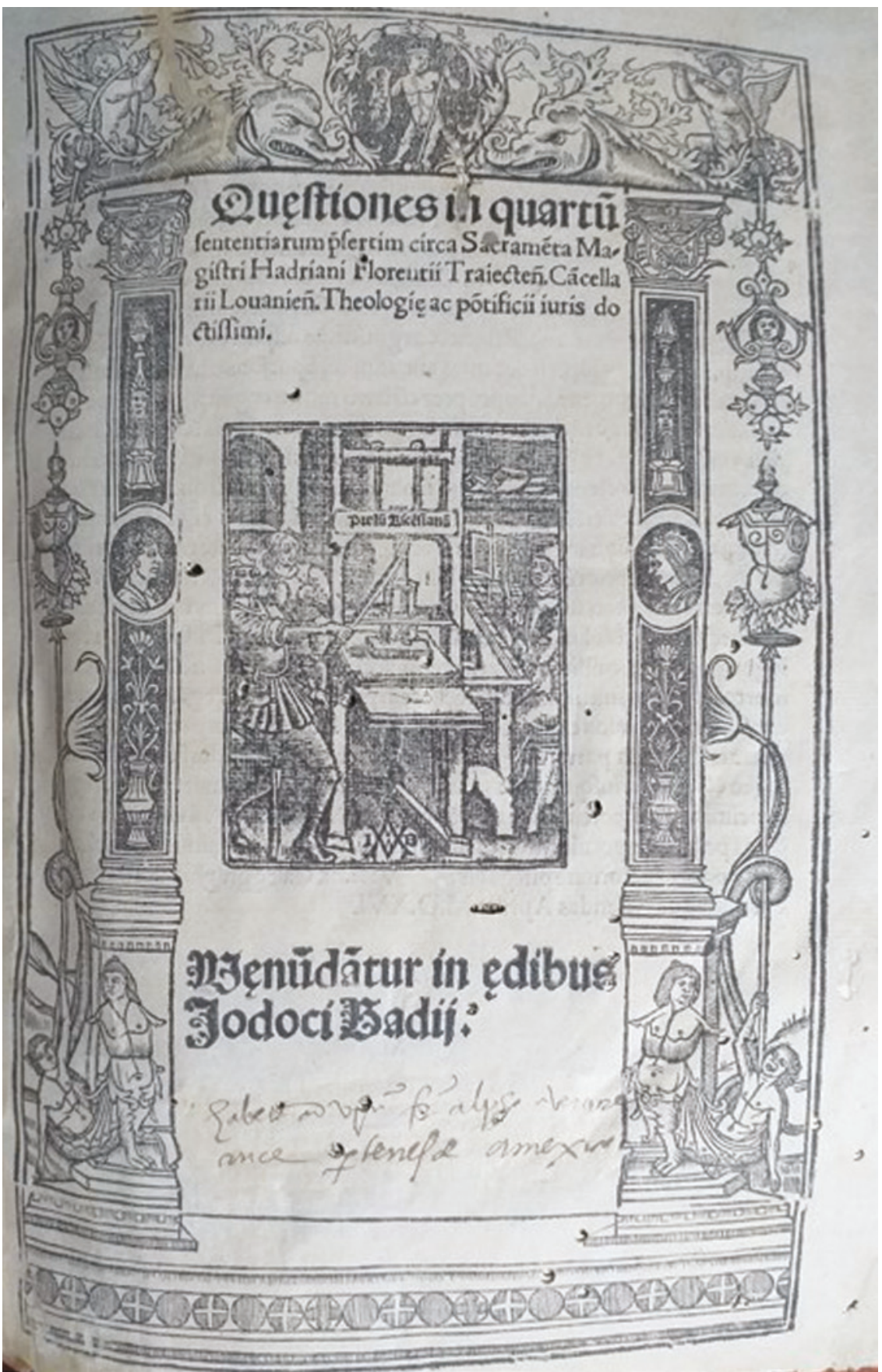

FIGURE 10.4 Hadrianus Florentius, Quaestiones in quartum sententiarum praesertim circa Sacramenta, Paris 1518: heirs of Josse Bade (Museo Regional Michoacano, 56948-9) 


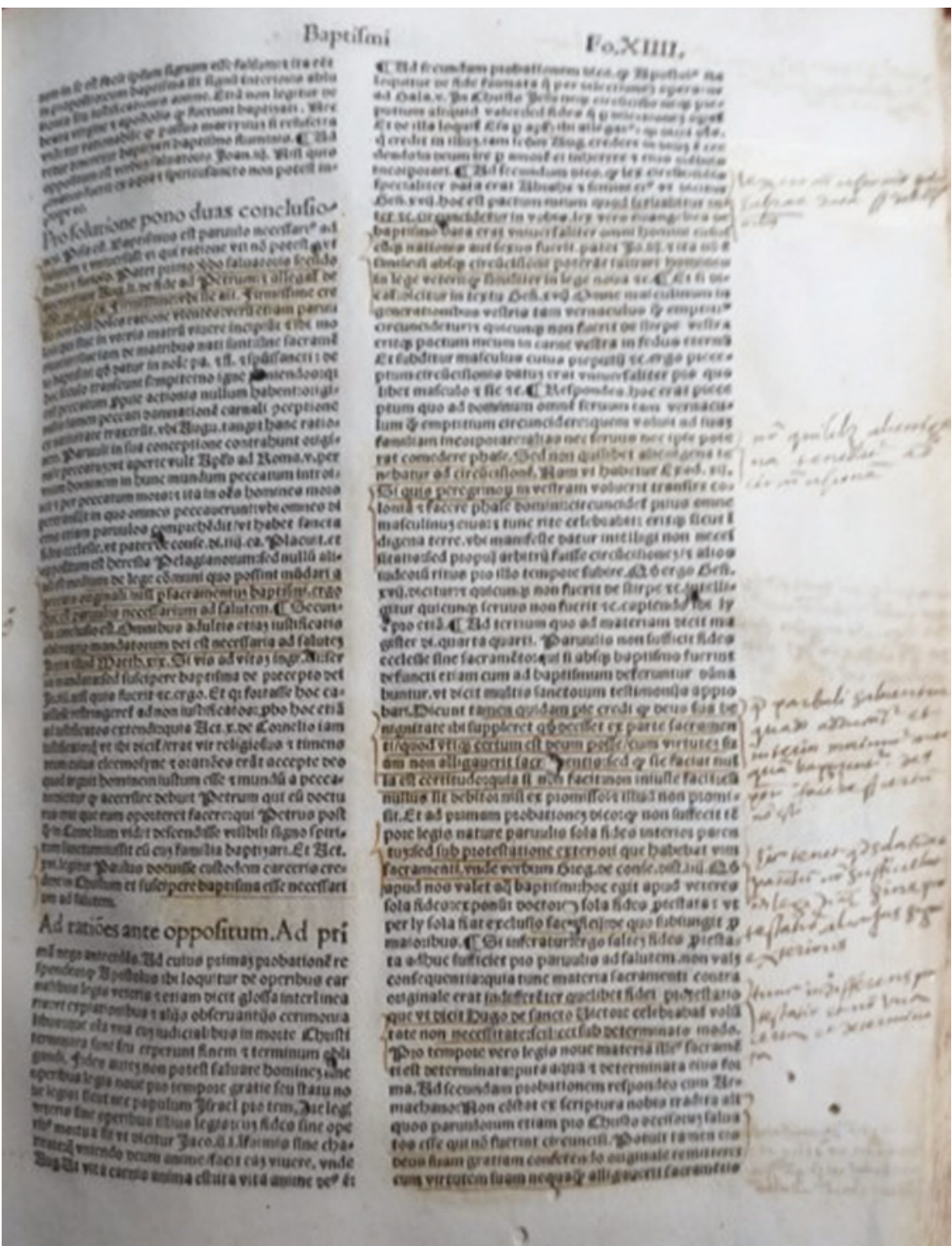

FIGURE 10.5 Hadrianus Florentius, Quaestiones in quartum sententiarum praesertim circa Sacramenta, Paris 1518: heirs of Josse Bade (Museo Regional Michoacano, 56948-9), fol. XIVr 
impozc Iubtre. $125 \mathrm{crgo}$ Б5 fi. non fucrit be ftirpe zc.intells: ion fuerit zc.capiendd'bt ly n quo ad materiam otcit ma १paruulis non fuffict fides fut fi abfo baptifmo fucrus aptifmum ocferuntur oâna Inctozum teftimoníg appzo lam pte credt $q$ oeus fua be boecfet exparte facramen peum polfe/cum virtutez fu Dentis:fed $Q$ fic factat nul in facit thon iniufte fact tecis romilfo: z Ittud non promt = lones of co: $\phi$ non fuffectit $t \bar{E}$ is fola fides intertoz parcn extertozi que babebat vim 5reg.oe confe.oift.tiu. Dos int:boc egit apud veteres en fols fidcs pteftats: $v t$ cyficif:oe quo fubtumgit p ir:ergo faltez fides piefta= uulis ad falutem.non vals tatcria facramentt contra quelibet fidet preteftatio o Elictozc celebrabaE volí etfub octerminato modo. noue materta illi' facramé qua $z$ octerminata eiug foz fonem refpondeo cum $2 \mathrm{Ar}$ s feriptura nobts tradita ali? p:o Chbufto occírozuz falua cuncifi.าpotuit tamen eis

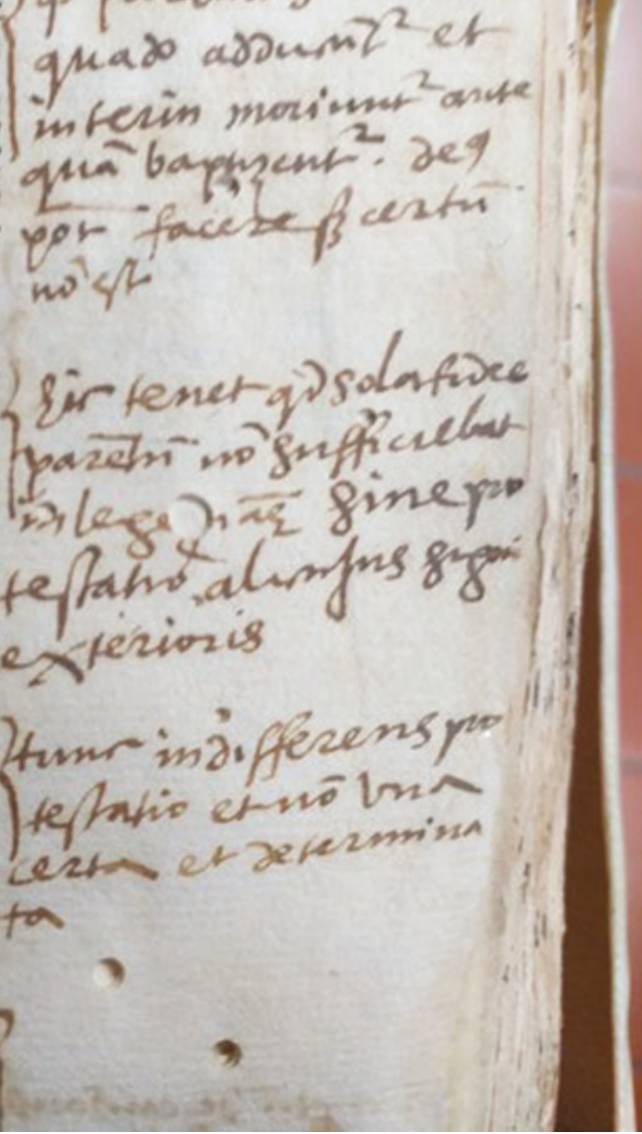

FI G U Re 10.6 Alonso de la Vera Cruz, Marginal annotations to Hadrianus Florentius, Quaestiones in quartum sententiarum praesertim circa Sacramenta, Paris 1518: heirs of Josse Bade (Museo Regional Michoacano, 56948-9), fol. XIVr 
law without the testimony of any external signs. Then, an indifferent profession of faith is not a sure and determined one. ${ }^{42}$

As Vera Cruz emphasised, following Hadrianus Florentius closely, a previously non-exteriorised profession of faith was not even considered as an assurance of salvation before Christ instituted the sacrament of baptism, a time when different rites (such as circumcision) were practiced by Jews as external manifestations of their faith in the one true God. Therefore, after the coming of Christ, an indifferent profession of faith by the parents, which differed in form and matter from what the Saviour had clearly instituted, could not be considered as a certain and safe way of proceeding. Although difficult to assume, the salvation of children who had died before being baptised, even if brought to the monastery while dying or just before, was not certain. This had to be properly explained to the natives who had already converted or were in the process of conversion so that they avoided any negligence with regard to the baptism of their children, who should be brought to a monastery to be baptised shortly after birth.

Contrasting these annotations with the printed books of Vera Cruz, one can see a clear reflection of his previous readings and the speculations he drafted, perhaps for the first time, as hesitant comments in the margins. Although the Speculum coniugiorum only dealt with the sacrament of baptism inasmuch as some of the theological and canonical prescriptions and doctrines in it were useful for judging by analogy some of the dilemmas concerning marriage, one can see important evidence of the intensity of Vera Cruz's reading of Hadrianus' Quaestiones in quartum sententiarum throughout the work. Vera Cruz also integrated his annotations to this important source of theology and canon law into his own writing. This was the case for the passage mentioned above, the conclusions of which were reaffirmed in the Speculum and localised (figure 10.7). That is to say, the authoritative opinion of Hadrianus, taken as valid and solid, was interpreted in the missionary context and some "new" conclusions applying to Mexican neophytes and infidels were drawn: the administration of the sacrament of baptism was the best way to ensure the salvation of new-born babies with the tacit consent of the parents being sufficient in

42 "Quod parvuli saluentur quando adduntur et interim moriuntur ante quam baptizentur, Deus potest facere sed certum non est. / Hic tenet quod sola fides parentum non sufficiebat in lege [natur]ae sine protestatione alicujus signi exterioris / tunc indifferens protestatio et non una certa et determinata", Vera Cruz, marginal annotations to Hadrianus Florentius, Quaestiones in quartum sententiarum praesertim circa Sacramenta, f. XIVr, MRM, 56948-9. 


\section{Articu. III. Deconfenfu. 29} inire, que faciunt illi, c civ lunt effe maritus \& vxor. Et talis confenfus fufficit ad fubsisatiă matrimonij. Sicut in baptizā Nota in fa te, qui ignorat quid fit baptifma, fufficit intëdere vt velit cir uorem neo ca paruulum id facere, qđa Chriftus inftituit,vel ecclefia tatho phito. licacirca paruulos baptizandos facit.Hęc Adrianus. Exquo Adria.in.-4 manifeftè eliciturverum effe matrimonium inter rudes homi de con. nes, quiv ix intelligunt quid fit ifte contractus, aut quẹ fit ifta obligatio: quod vinculum matrimonii, quo modo indiffolu bile lit: dummodo in contrahendo id intendant facere, quod contrahentes faciunt: \& ficut eft vf fis contrahentium.

FIGURE 10.7 Alonso de la Vera Cruz, Speculum coniugiorum, Alcalá 1572: Juan Gracián (Biblioteca de la Universidad de Sevilla, A Res. 59/5/22 (1)), 29

order to administer the sacrament, even if those parents, as was the case for Indian neophytes and infidels, were not yet aware of it or did not understand the nature of baptism as a sacrament. Vera Cruz said that, in this situation, "it is enough to understand that he/she wants to do with the child what Christ instituted and what the Catholic Church does with children to be baptised".43 Interestingly enough, Vera Cruz wrote in the margins of this paragraph that it was, in fact, a "Note in favour of the neophyte to Hadrianus's In quartum sententiarum, De consenso". ${ }^{4}$ A process of normative knowledge production which began as a handwritten reflection in the margin of a certain selected reading ended up in the printed note of a book, where Vera Cruz explicitly stated that a concrete, local, and problematic case was solved by interpreting the authority he consulted some years before in the missionary context.

With such rich handwritten and printed materials, it would be possible to make a very detailed analysis of the way in which knowledge, especially in its normative dimension, was intensely translated between the European and Mexican spheres and produced in the region of Michoacán during the mid16th century. Analysing such a wide corpus of marginalia and comparing it

43 "Et talis consensus sufficit ad substantiam matrimonii. Sicut in baptizante, qui ignorat quid sit baptisma, sufficit intendere ut velit circa paruulum id facere, quod Christus instituit, vel ecclesia catholica circa paruulos baptizandos facit. Haec Adrianus", Vera Cruz, Speculum coniugiorum (1572), Pars I, Art. III, 29.

44 "Nota in favorem neophito. Adria. in. 4 de con.", Vera Cruz, Speculum coniugiorum (1572), Pars I, Art. III, 29. 
with the contents of the writings of Vera Cruz is, in any case, a long-term study requiring several years of work before detailed results will be available.

\section{The Salamanca Masters in the Speculum Coniugiorum: Vitoria "by Ear"; the Overwhelming Presence of Soto, Covarrubias, and Azpilcueta; the Decisive Authority of El Tostado}

As Grijalva and other chroniclers of the Augustinians of New Spain emphasised, Vera Cruz's compulsive acquisition of books and establishment of libraries were linked to motives far removed from the attitude of the collectionneur bourgeois of our times. He bought and brought the books he needed as working tools to the Augustinian convents of Michoacán. These books and libraries were, in fact, the instruments he employed to successfully fulfil his mission as an instructor of less well-informed friars who had not been trained at universities or colleges. He had to train missionaries and the future teachers of missionaries who followed him from one monastery to another in some cases, ${ }^{45}$

45 Vera Cruz's double mission was attested to by the chronicles. While most of his disciples, permanent residents in a certain monastery and destined to be missionaries in that specific region ("ministros") only received a kind of practical, superficial training of one or two years, another group of selected friars ("estudiantes"), the future Augustinian elite, were determined by their order to exercise more important offices than the simple administration of a doctrina. They followed Vera Cruz through various monasteries for five, six, or more years, attending the different courses of arts and theology that every student needed in order to obtain a university degree at this time. This dynamic can be observed when, after one and a half year of residence and teaching at the monastery of Tacámbaro where he was prior $\left(1545^{-1546)}\right.$, Vera Cruz departed for Atotonilco, $45^{\circ}$ kilometres east, bringing students of arts and theology with him. "Dio principio a su lectura N. V. Maestro y al tiempo mismo a administrar las grandes doctrinas de aquella tierra, pero como es de los sabios mudar de sentir, N. V. P. Mro. retractó su antiguo sentir de que administrasen los estudiantes y el que en Tiripitío siendo súbdito aprobó con su obediencia el primitivo dictamen, ahora que es en Tacámbaro prelado y como tal dueño de la acción, viendo que los ministros eran ya bastantes, halla por más acertado que éstos se ocupen de las doctrinas y que los estudiantes se ejerciten en aprender las ciencias; así se hizo, para la cual renunció el priorato e irse con los estudiantes a Atotonilco", Escobar, Americana Thebaida, 254-255. In terms of teaching, the large variety of strings to Vera Cruz's bow made him, without doubt, a special case. Many universities forbade teaching two or more chairs simultaneously. Moreover, it was not common for a single man to be able to teach all the courses of arts and theology with an acceptable level of proficiency. Vera Cruz's solid education, a kind of precious rara avis in the American context, led the Augustinian Order to entrust him with a huge number of academic, representative, and government tasks from his youth. "Artes y Teología le mandaron leer a un mismo tiempo, haciendo nuestro Padre Maestro solo, el gasto de muchos catedráticos pues aunque como 
and needed not only to acquire knowledge of the classical authorities about the proper way of teaching the Gospel and administering the sacraments, but also sound and clear criteria for how to apply this complex and sometimes discordant normative patrimony in a context of radical cultural difference between missionaries and potential converts.

A recent study by Quijano has shown the important and almost incredible number of sources which Vera Cruz, writing from distant Mexico, referenced in his treatise De dominio infidelium, ${ }^{46}$ an aspect which Aspe's contribution to this book also highlights. The importance that Vera Cruz gave to the exhaustive reading and study of the relevant classical and contemporary literature before writing, determining his own criteria, and taking decisions about any matter was also reflected in his Speculum, where the discussion of very specific authorities on different problematic sub-issues related to the general topic of marriage (sacramentality of marriage, clandestine marriage, impediments, etc.), was consistent and meticulous.

In the editions of 1562 and 1572 , Vera Cruz added a final Peroratio in which he stated that he continued reading many books related to the topic of marriage after the first edition of the Speculum (1556), literature that, he informed the reader, had been duly integrated into these second and third editions of the treatise. ${ }^{47}$ The detailed references to these new publications, which can be found throughout the texts, demonstrate that Vera Cruz was quite honest in comparison with other cases at a time when writers and printers, driven by lucrative commercial gains, used to bombastically announce new, augmented, and revised editions of books that were, in fact, old, and had been only slightly modified. ${ }^{48}$ For example, reading the different editions of the

el sol, era uno en las Indias como refiere vuestro Calancha, se vio como tres en cierta ocasión el sol. Viéronlo en la encomienda del Porco, siete leguas del Potosí en el Perú y acá vemos a nuestro sol hecho tres, leyendo dos cátedras de Teología prima, vísperas, y la tercera de filosofía. Asimismo le ordenaron que entrase con sus discípulos, las Pascuas y vacaciones, a predicar a la tierra caliente para vivificar con sus rayos aquellas nuevas plantas". "Salía juntamente a predicar a aquellos pobrecitos indios rústicos y bárbaros, un tan gran Maestro, un doctor de Alcalá y Salamanca, sin molestarse de su natural simpleza, antes allí era adonde más eficacia ponía su gran caridad", Escobar, Americana Thebaida, 121 and 159 .

46 Quijano Velasco, "Las fuentes del pensamiento político de Alonso de la Veracruz".

47 "Et quidem licet ante plures annos fuerit compositum, sicut illa quae ante ad rem attinentia in diversis tractata doctoribus legimus, et perlegimus, ed adduximus, sic quae postea scripta sunt, antequam opus escuderetur, perlustravimus, doctoribusque ipsis citatis in medium produximus, quando oportuit", Vera Cruz, Speculum coniugiorum (2013), Pars III, "Peroratio", 342. 
Speculum, one can see that he followed the various editions of Azpilcueta's Manual de confessores with close attention, ${ }^{49}$ as it proved particularly useful for the mitigation of some of his own positions and for the integration of the new normativity related to clandestine marriage approved by the Council of Trent (XxIV Session, 1563) in the 1572 edition of the Speculum. ${ }^{\circ 0}$ Only two years after its publication in Valladolid, Vera Cruz made extensive use of the Capitulo veynte y ocho de las Addiciones del Manual de Confessores (1570), ${ }^{51}$ written by Azpilcueta to update his Manual in accordance with the Tridentine decrees. Confronted with the need to revise his Speculum, Vera Cruz therefore drew some inspiration from the adaptations that other Salmantine scholastics had been obliged to introduce to their own legal and moral-theological writings.

Moreover, the Salamanca and Alcalá editions contained accurate tables indicating all his sources, properly divided into "orthodox and classic fathers" (46 authors), "scholastic theologians" (38), "civil and canon lawyers" (69), "summistae" (10), and "natural and moral philosophers"52 (31). Looking at this kind of proto-academic exhaustive bibliography, including 194 authors (figure 10.8), ${ }^{53}$ one can imagine the size and technical completeness of the libraries, established as places for him to work, that Vera Cruz founded. Intellectually, it would also be difficult to find a stronger and more illustrative example of the way in which law, moral theology, and philosophy intermingled in the writings of the most prominent members of the School of Salamanca, even in those written in remote and unknown places such as Tiripetío, Tacámbaro, and Atotonilco.

Apart from the long list of classical sources quoted in the Speculum, Vera Cruz proved that he knew contemporary literature very well, for example, many of the treatises that had been written as part of the controversy caused by the

49 On the important changes effected in the Manual de confessores during Azpilcueta's lifetime, see Bragagnolo, "Managing Legal Knowledge in Early Modern Times: Martín de Azpilcueta's Manual for Confessors" and "Les voyages du droit du Portugal à Rome. Le 'Manual de confessores' de Martín de Azpilcueta (1492-1586) et ses traductions".

50 "Item, et est advertendum, quod etsi clandestina matrimonia modo sint irrita, et penitus, nulla post Concilium Tridentinum, si in aliqua dioecesi, ubi sub excommunicatione est prohibitum contrahere, contrahant: qui impedimentum habent, incidunt in excommunicationem quia ratio, quare excommunicatio posita est manet semper, scilicet, ad vitanda scandala et contentiones, quae oriri solent, ex huiusmodi furtivis contractibus, sic sentit doctissimus Navarro, in additionibus ad Manuale in c. 28. in additione ad c. 22. n. 7o", Vera Cruz, Speculum coniugiorum (2009), Pars I, Art. 10, 204.

$5^{1}$ Azpilcueta, Capitulo veynte y ocho de las Addiciones del Manual de Confessores.

$5^{2}$ Vera Cruz, Speculum coniugiorum, Pars III, "Peroratio", 652-655.

53 It is important to take into account that, given that Vera Cruz only mentioned the authors he had referred to as auctoritates without referencing individual books or writings, his bibliography would have been much more extensive if written according to contemporary academic criteria. 


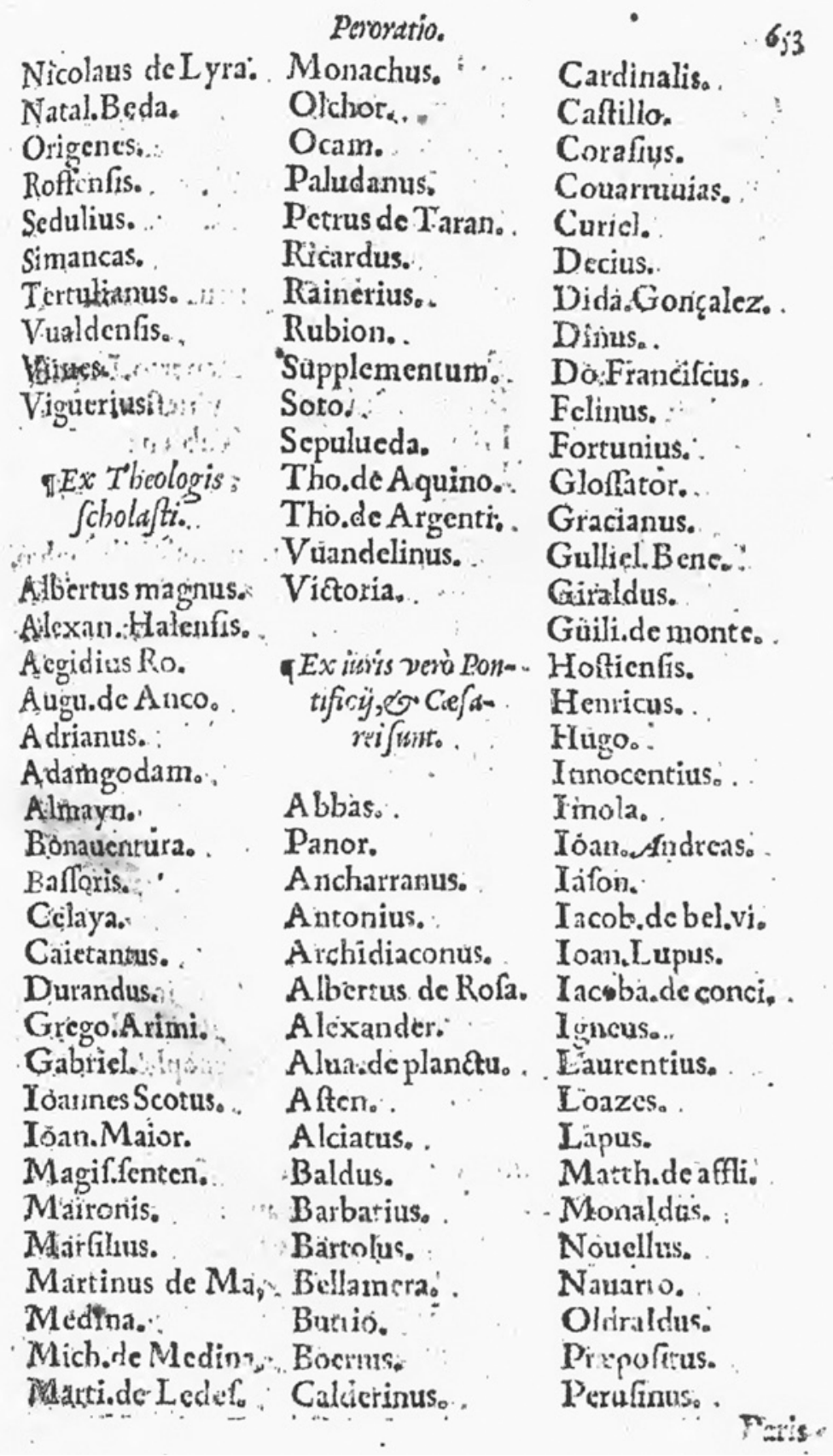

FIGURE 10.8 Alonso de la Vera Cruz, Speculum coniugiorum, Alcalá 1572: Juan Gracián (Biblioteca de la Universidad de Sevilla, A Res. 59/5/22 (1)), 653 
annulment of the marriage between Henry VIII and Catherine of Aragon in the late 1520 and early 153 os. Interestingly, books on this subject that had been published by theologians such as Alonso Ruiz de Virués (Ulmetanus) and John Fisher (episcopus Rossensis), and jurists such as Jerónimo Curiel and Fernando de Loazes ${ }^{54}$ were quoted at length and interpreted within the American missionary context in relation to the impediments of affinity and consanguinity.

Vera Cruz's knowledge and use of the Salamanca tradition was also extensive: El Tostado (1400?-1455), Domingo de Soto (1494-156o), Diego de Covarrubias (1512-1577), and Martín de Azpilcueta (1492-1586) were the Salamanca masters whom Vera Cruz quoted most. In particular, Soto's De iustitia et iure, first printed in Salamanca in 1553 (three years before the Speculum), was a reference for many specific points regarding marriage, debitum [due], divorce, adultery, and consanguinity. ${ }^{55}$ Soto's masterpiece was also especially taken as an authoritative reference with regard to the general philosophical maxims behind the division between the first and second principles of natural law - together with the pioneering classification between the types of law in Thomas Aquinas ${ }^{56}$ - a division that, as is well known, functioned as the School

54 Ruiz de Virués, De matrimonio regis Angliae; Fisher, De causa matrimonii Serenissimi Regis Angliae; Curiel, Tractatus de Concilio Generali \& de matrimonio regis Henrici octavi Anglici; Loazes, Tractatus in causa matrimonii Henrici et Catherinae Angliae regum.

55 Some examples of the many passages in which Vera Cruz reproduced positions of Soto without any kind of reservation include divorce, Pars III, Art. 4, 112; capital punishment for adulterous women, Pars III, Art. 4, 112; seeking and giving the marital debitum [due] in case of doubts and scruples of conscience, Pars III, Art. 13, 248; and marriage between blood relatives in the direct line as null and void, Pars II, Art. 22, 325. Pages are quoted according to the contemporary edition (2009-2013).

56 See the long explanation given by Alonso de la Vera Cruz when he addressed the theoretical grounds for the distinction between first and second (derivate) principles of natural law and the difference between various kinds of law in general. "Prima conclusione. Lex naturalis quantum ad prima sua principia, quae per se sunt nota, est eadem apud omnes gentes: nec aliquam variationem patitur [...]. Ob hoc $\mathrm{S}$. Thomas dicit, quod lex naturalis quantum ad illa, quae sunt de secundis praeceptis, deleri potest a cordibus hominum, vel propter malas persuasiones: vel propter pravas consuetudines, et habitus corruptos, sicut olim apud Germanos latrocinium non reputabatur peccatum, si extra fines civitatis esset", Vera Cruz, Speculum coniugiorum, Pars II, Art. 7, 154-158. Both in the main text and in margine, Vera Cruz pointed directly to Aquinas's Prima Secundae (q. 94, arts. 2, 6) as the authoritative work in which his readers could find a more detailed explanation of natural law. In these passages of the Speculum, Soto's De iustitia et iure (in passages such as Book 1, q. 4, art. 4 and Book 2, q. 1, art. 3) was cited as the most up-to-date revision of Aquinas's doctrines and its proper framing in many contemporary legal discussions. Other classical authors, such as Aristotle, Cicero, Isidore of Seville, and Lactantius, were taken as authorities of this important philosophical distinction between the types of natural law, but their supporting roles were considerably less important than the pride of place extended to Aquinas and Soto. 
of Salamanca's red line in many discussions on how missionaries, confessors, and ecclesiastical judges should proceed with regard to certain problematic indigenous customs. The general perspective of Salamanca authors was that, while the second principles of natural law were not self-evident and could, therefore, be ignored, the first principles of natural law were inscribed within human reason and self-evident to every rational being. And so, no excuse could be given by the Indians or their religious tutors if those first principles were not respected. These criteria applied even to the most barbarous inhabitants of the New World. Soto's considerations on what belonged to the first principles of natural law were usually followed by Vera Cruz, who thought, for example, that masturbation, simple fornication, and polygamy were not intrinsically and evidently bad. ${ }^{57}$ Even so, both Soto and Vera Cruz agreed that acts such as homicide and marriage between parents and their own children was absolutely illicit and immoral.

Vera Cruz's perspectives were singular inasmuch as they were more flexible than those of his Salamanca masters and colleagues as far as indigenous customs were concerned. The particularity of some of his positions was closely linked to the specific missionary commitments that distinguished Vera Cruz's background from the mainly academic trajectories of Soto, Vitoria, and later Iberian members of the School of Salamanca. In some exceptional cases, Vera Cruz even dared to disagree with the much more famous Salamanca masters in order to justify some of the most problematic indigenous customs known to him. An interesting case is that of marriages between siblings, a custom common to the Inca nobility, which, for Vera Cruz - and against Soto's criteria -, could be tolerated to avoid any kind of unrest and violent resistance on the part of the allied indigenous elites still in the process of conversion to Christianity.

Similarly, it is said that, in the province of Peru, although not everywhere, among the so-called Inca princes, twins are joined in marriage, and that this is not considered to be a vice. We do not find this custom or usage in the province of Michoacán or in the province of Mexico. However, if such

57 For Vera Cruz - following Soto's De iustitia et iure - "pollutione voluntaria", "concubitus vagus", and other sexual practices deviating from the contemporary normativity were capital sins that could, nevertheless, be ignored in the case of the most rustic Indians because their wickedness was not evident according to the first principles of natural law, "Et quidem quod vagus concubitus mortale sit, potuit ignorari apud barbaros, ut placet Soto lib. 1 De iure et iustitia q. 1. arti. 4. ad primum argumentum et quaestio 4. eiusdem li. arti. 4. idem li. 2. q. 1. art. 3. Et forte vitium contra naturam; nam tam sunt rudes, et ferales aliqui homines, ut invincibiliter potuerit ignorari", Vera Cruz, Speculum coniugiorum (2013), Pars III, Art. 15, 262. 
a case were found in any province, the marriage would be true and the spouses should not be separated if they converted [...]. Indeed, contrary to such precepts of natural law, custom, or the law may prevail. It follows, then, that, where this [practice] is a custom, marriage is legitimate $[\ldots]$. And so, those who say that the [matrimonial] union of siblings is forbidden by natural law, as Soto says (lib. 2. De Iustitia et iure, q. 3. art. 1. et 8), must be understood as referring to the second degree of natural law and not to the first. In fact, the same author (ibid., art. 4) maintains with Cajetan and others that Abraham and Sarah were truly siblings and not first cousins. Therefore, since the human race had already multiplied [at this time], if this were so indecent, they should not have married. However, the opposite opinion (i.e., that [this kind of marriage] is forbidden by natural law) is also probable. ${ }^{58}$

Interestingly, Vera Cruz contradicted Soto on this specific point, but he did so through one of the most characteristic resources of the Salamanca method of argument: the distinction between first and second principles of natural law he had learnt precisely from Soto, Vitoria, and other Salamanca masters. When these kinds of exceptional disagreements occurred, Vera Cruz admitted that he was only defending a probable opinion - that is to say, that the contrary opinion was also based on sound reasons and authorities favouring the opinion as well as on a certain degree of probability, thus showing himself open to changing his mind if someone gave a better resolution for the case or a superior authority settled the issue.

It is not the purpose of this chapter to enter into a detailed analysis of the points for which the authorities of Soto, Azpilcueta, and Covarrubias - the contemporary Salamanca masters most quoted in the Speculum - were referenced throughout the treatise. An illustrative example in which all of them

$5^{8}$ "Et similiter in provincia del Peru aiunt, apud principes quos Inga vocant, licet non in omni loco, apud quos fratres uterini inter se matrimonio iunguntur. Neque id vitio datur: quam consuetudinem, vel usum non invenimus apud provinciam Michoacanensem: neque apud Mexicanam. Tamem si aliqua de novo inveniretur, verum esset matrimonium, neque essent disiungendi, si converterentur [...], nam contra talia praecepta iuris naturae praeualere potest consuetudo, vel lex. Sequitur ergo, quod vbi consuetudo esset, legitimum esset matrimonium [...] Et sic qui dicunt de iure naturae prohibitum esset fratres coniungi, ut Soto lib. 2. de iure et iustitia q. 3. art. 1. et 8. debent intelligi, quod in secundo gradu, et non in primo gradu iuris naturae. Et quidem argumentum est, quod idem author ibi art. 8 cum Caietano et aliis tenet, Abraham, et Saram vere fuisse fratres, et non fratrueles: ergo cum iam esset multiplicatum genus humanum, si tam indecens esset, fratres non deberent iungi. Contraria tamen sententia, scilicet, esse iure naturae prohibitum, suam habet probabilitatem", Vera Cruz, Speculum coniugiorum (2013), Pars II, Art. 22, 336-338. 
were mentioned - together with the Salamanca archenemy, Juan Ginés de Sepúlveda ${ }^{59}$ - as relevant authorities can be found in Vera Cruz's resolution of the issue represented by the case of the person who, despite having received the ecclesiastical command of remaining together with his/her current partner, still had some speculative doubts as to their true and valid spouse (given up for dead, missing, etc.). Could this person give and seek the conjugal debitum [due] without sinning?

If anyone has doubts about the true spouse and, once the Church's mandate to remain together [with the current spouse] arrives (since there is no evidence to the contrary), if [he or she] has no doubt with regard to giving and seeking [the conjugal debitum], [he or she] may ask for and give it without sinning [...].This conclusion, as regards rendering the due, is expressly supported by a certain doctor [Sepúlveda] in Chapter 9 of the dialogue De ratione dicendi testimonium. It is also sustained by Master Soto in the Relectio de ratione tegendi, et detegendi secretum, Part 3. q. 2. Covarrubias maintains the same in the epitome (4. Decreta. 2. par. c. 7 . 2. num. 9.). The same is held by Soto in De iustitia et iure, Lib. 4, quaest. 5, artic. 4, where, in the last words, he says that [even] when [he/she] has doubts concerning the legitimate spouse, [he/she] may render the debitum. And this is also very elegantly maintained by Doctor Navarro in his De poenitentia, d. 7, c. Si quid, nums. 101 and 102. I add, to conclude, that [he/she] should not only give, but also ask for the debitum, once the mandate of the Church has come. ${ }^{60}$

This passage is interesting for many reasons. Apart from the previously mentioned presence of important Salamanca authorities, it provides another interesting example of the trend towards a flexible implementation of Christian

59 Vera Cruz here quoted Sepúlveda's dialogue De ratione dicendi testimonium in causis occultorum criminum (1538).

6o "Si quis dubitat de vero coniuge, et adueniente praecepto Ecclesiae de commanendo simul (quia non constat de contrario) si non dubitat quantum ad reddendum, et exigendum, poterit sine peccato exigere, et reddere [...]. Hanc conclusionem quantum ad hoc quod est reddere, expresse asserit quidam doctor [Sepúlveda] in dialogo de ratione dicendi testimonium capit. 9. Eam etiam tenet Magister Soto in relectione, de ratione tegendi, et detegendi secretum, membro. 3. q. 2. Tenet idem Covarrubias in epitome 4. Decreta. 2. par. cap. 7. 2. numer. 9. Et idem Soto De iustitia et iure. lib. 4. quaest. 5. artic. 4. in ultimis verbis ubi dicit, quod quando dubitat de legitimo viro, potest reddere. Et elegantissime doctor Navarro in suo De poenitentia d. 7. cap. Si quis. numer. 101. et 102. Et quidem ego pono in conclusione, quod potest non solum reddere, sed petere, adveniente praecepto Ecclesiae", Vera Cruz, Speculum coniugiorum (2013), Pars III, Art. 18, 296-298. 
matrimonial and sexual normativity in the missionary context. ${ }^{61}$ The kind of doubts and scruples of conscience regarding previous cohabitants and sexual partners emerged above all in an American context in which divorce and repudiations were frequent and traditionally tolerated, as Vera Cruz himself asserted in his Speculum. To search for the first, legitimate spouse seemed like a wild goose chase in many cases, leading to unsuccessful inquiries, intentional lies, and fierce resistance from the natives. Writing from a realistic perspective, Vera Cruz took stock of the situation and opted for a policy of ecclesiastical decisionism and tabula rasa: any doubt and scruple with regard to previous spouses ended once the current relationship was sanctioned by the Church as the legitimate marriage. In the case of impediments of consanguinity, Vera Cruz again went a step further than his masters in Salamanca: in such a situation, not only giving but also seeking the debitum should not be considered sinful.

It is also interesting to consider that, within the wide constellation of authors who had written about marriage or taught about the sacraments at the University of Salamanca, Vitoria was almost absent from Vera Cruz's Speculum coniugiorum. As is well known, Vitoria wrote and delivered his Relectio de matrimonio in a period (January 1531) when the whole Christian world debated the controversial annulment of the marriage between Henry viII and Catherine of Aragon. Vera Cruz took Vitoria's contribution into account and quoted the Relectio de matrimonio five times in the first part of the 1572 edition of the Speculum and once in the third part. Vitoria made his appearance in the treatise as an almost irrefutable authority in terms of very general points such as the necessity of the consent of the spouses for any authentic and legitimate marriage ${ }^{62}$ and the consideration that marriage between parents and children was absolutely contrary to the first principles of natural law. ${ }^{63}$ However, Vitoria almost disappeared in the second part of the Speculum, in which Vera Cruz addressed marriages contracted between the infidels of the New World. Vitoria was only quoted twice and in a very general way, without explicit reference to any particular writing or relectio.

61 On Vera Cruz's broad-minded approach to the customary sexual practices of the natives, tolerable as long as they did not contravene the first principles of natural law, see Aspe Armella, "Análisis del placer y la sexualidad matrimonial en Alonso de la Veracruz", 39-40.

62 Vera Cruz, Speculum coniugiorum (2009-13), Pars I, Art. 2, 78, 85; Pars I, Art. 19, 310; Pars I, Art. 29, 396; Pars III, Art. 12, 230. There was also one, single reference to Vitoria's Relectio de potestate ecclesiastica in Pars III, Art. 20, 332.

63 Vera Cruz, Speculum coniugiorum (2009), Pars I, Art. 43, $55^{2}$. 
How can we explain the limited presence and impact of Vitoria on the writings of Vera Cruz - despite his having written a whole relectio on the subject (De matrimonio) and being considered as one of the most cherished disciples of the "founding father" of the School by the historiography? ${ }^{64}$ We should firstly consider that all the writings quoted by Vera Cruz - be they important treatises, such as the De sponsalibus ac de matrimonio (In librum quartum decretalium epitome) by Diego de Covarrubias and Azpilcueta's De poenitentia, or opuscula, such as the previously mentioned dialogue of Sepúlveda or Soto's Relectio de ratione tegendi et detegendi secretum - had been printed several times in the Iberian Peninsula during the 154 os and 155 os. ${ }^{65}$ The extensive catalogue of authorities used by Vera Cruz demonstrates that, even if writing in distant Mexico since 1536, he had managed to acquire the relevant books he needed for his own treatise on marriage. The Augustinian friar was, in fact, very up to date with regard to the contemporary juridical and theological literature. Even very recent books such as Soto's De iustitia et iure, first printed in Salamanca in 1553, were quoted at length in the first edition of the Speculum, which was completely written in Mexico.

64 As in many other cases, this is more a common belief of a very naïve historiography than a confirmed reality. In any case, we have found affirmation that Vera Cruz was one of Vitoria's favourite students in early Augustinian chronicles, the works of 19th century bibliographers such as José Mariano Beristáin de Souza, and in most of the writings dedicated to Vera Cruz during the 2oth century. "Estudió las letras humanas en Alcalá, y la filosofía y teología en Salamanca, donde fué discípulo muy preferido del ilustre dominicano Francisco de Victoria, quien confirió á nuestro Alonso el grado de maestro, por particular commission de la Universidad", Beristáin de Souza, Biblioteca hispano americana setentrional, Tomo III, 264. "En Alcalá estudió gramática y retórica, y más tarde, en Salamanca, filosofía y teología. En este lugar fue discípulo de Francisco de Vitoria, gloria de la teología escolástica y fundador del derecho internacional moderno. Es de creerse, por lo que adelante se dirá, que entre ambos, y no obstante la diferencia de edades, hubo una estrecha amistad, y que Alonso pudo penetrar en el mensaje más íntimo del magisterio vitoriano", Gómez Robledo, "El problema de la conquista en Alonso de la Veracruz", 380. Many of these commonly held positions have been refuted through archival evidence in recent publications. For example, it is now clear that it was in fact the nominalist philosopher and rival of the Salamanca Dominicans, Juan Martínez Silíceo, who was Vera Cruz's padrino de grado de bachiller; Vitoria did not grant any degree to Vera Cruz. See Ramírez González, "Alonso de la Veracruz en la Universidad de Salamanca", 648. The master's and doctoral degrees were granted to Vera Cruz in Mexico. See Ramírez González, "Fray Pedro de la Peña y la fundación de la Real Universidad”, 19. See also Aspe Armella's chapter in this book.

65 Covarrubias, In librum quartum Decretalium, De sponsalibus, Epitome, ac de Matrimonio, Salamanca, Juan de Junta, 1545; Azpilcueta, In tres de poenitentia distinctiones posteriores commentarii, Coimbra, João Álvares and João de Barreira, 1542; Soto, Relectio de ratione tegendi et detegendi secretum, Salamanca, Pedro de Castro, 1541. 
Unlike with other books, Vera Cruz could not have read Vitoria's Relectiones theologicae (including De matrimonio) before the publication of the first edition of his Speculum in 1556. The princeps of the famous Relectiones only appeared in Lyon a year later. ${ }^{66}$ Vera Cruz, always prompt to acquire, read, and assimilate new publications, used and quoted this French edition while preparing the second edition of the Speculum coniugiorum (1562), in which Vitoria's De matrimonio was quoted three times. ${ }^{67}$ It is important to emphasise that it was only superficially integrated: Vitoria's text was only quoted in the margins as a supplementary authoritative reference for positions Vera Cruz had already defended in 1556 . In fact, as can be seen by comparing the two editions, the main text was not even reformulated (figures 10.9 and 10.10). Vitoria's authority, therefore, helped only to extend the already long list of authorities to whom Vera Cruz referred and did not imply any kind of change in the doctrinal content of the treatise. Obliged to amend his treatise on marriage once again after the Council of Trent, Vera Cruz reread Vitoria's De matrimonio and, as mentioned earlier, made two further references to the text in the third and definitive edition. In any case, these last references also played a similarly superficial role in the rewriting process.

It is clear that by the time Vera Cruz could access Vitoria's Relectiones, the doctrines and text contained in the Speculum were already well established. In fact, taken as a whole, the differences between the three editions of the treatise are but minor. Even if obliged to harmonise the Speculum with the Tridentine decrees (particularly those related to clandestine marriage), Vera Cruz did so hastily and was reluctant to modify the doctrinal guidelines of the treatise, as some passages of the 1572 edition indicate. ${ }^{68}$

66 Vitoria, De matrimonio, in Vitoria, Relectiones theologicae XII, Lyon, Jacques Boyer, 1557, Tomus I, 426-487.

67 Vera Cruz, Speculum coniugiorum (1562), Pars I, Art. 19, 105; Pars I, Art. 29, 136; Pars III, Art. $12,5^{22}$. Only a single reference to Vitoria's Relectio de potestate ecclesiastica was integrated into the main text, "De quo videndus sit Victoria in relectione de potestate Ecclesiastica, \& alii", Pars III, Art. 20, 566. Even if few, these quotations prove that Vitoria's Relectiones circulated in Spain even before being printed in Salamanca by Juan de Canova in 1565 .

68 "Verum in istis temporibus usus clandestini matrimonii primo modo, quando sine testibus, non solum damnatus est, sed contractus non tenet, quia in Concilio Tridentino tales clandestine contrahentes sine testibus, inhabiles sunt, ad sic contrahendum, ut diximus, et in fine latius explicandum est, et adverte in sancto Concilio Tridentino, ita fuisse contra versum de clandestino matrimonio inter patres, ut plusquam quinquaginta episcopi ex ibidem congregatis, dicerent non esse irritanda clandestina matrimonia; tandem prevaluit alia pars, et ex consilio omnium diffinitum est", Vera Cruz, Speculum coniugiorum (2009), Pars I, Art. 10, 204. Vera Cruz's disagreement with some of the conclusions of the Tridentine Council, inadequate and difficult to apply in the missionary context, is an interesting and wide topic to which I should like to dedicate a publication in the future. 
nojcat ea m:non est verum matrimonium. i non ad jit rouus confenfus. Kicardus autem ponit exemplum in confanguitate, er af finitate. Et do. Panor fimiliter, dicens fic. Si duo conjanguinei cố trabant fic:egotecum contrabo: $i$ Papa difpen $\int e t$, Papa difpent

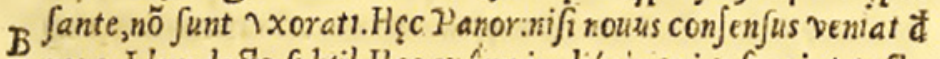
nouo.Idcm docto. Jubtil. Hęc quámuis aliás in pri.p fucrint tacta Sco.d.35.

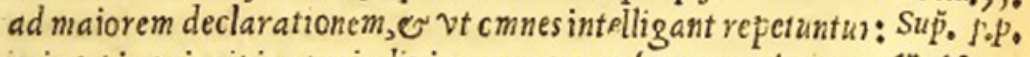
quia vt in principio operis diximus, ex propolito naterio m $\left(2-a r_{0}, 43\right.$.

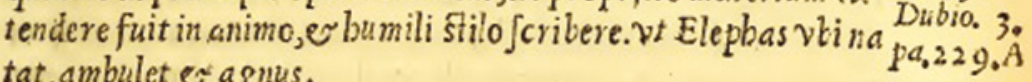
tat, ambulet es agnus.
प] Adboc o matrimonium quod a pr
principio fuit mullum
2.conclu,

Figure 10.9 Alonso de la Vera Cruz, Speculum coniugiorum, México 1556: Juan Pablo Bricense (John Carter Brown Library, BA556.A454s), 6 o1

:522 Tertia.P. Speculi Coniugiorum.

Bertas, cognofcat cam, non eft verum matrimonium, fi non adfit $\mathbf{A}$ nouus confenfus. Ricardus autem ponit exemplum in confanguinitate,\& affinitate: \& Panoro inquit. Si duo confanguineicá

rito. I relec. trahant fic, Ego tecum contraho, fi Papa difpenfet, Papa difpen

de matrimo. fante, non funt vxorati:nifi nouus confenfus veniat denouo. Ide ses.d.35. sin̈.p,p.arti. 44dw.2. docto.fubtil. $\mathrm{H} x \mathrm{c}$ quanuis aliàs in pri.p.fucrint tacta, ad maiorem declarationem, \&vt omnes intelligant, repetuntur : quia vt in principio operis diximus, ex propolito materiam extendera fuit in animo, \&humili ftylo fcribere,vt Elephas vbi natat,ambulet \& agnus.

\section{Cosclu.2. - Ad hoc, $\$$ matrimonium, quod à principio fuit nullum pro-}

FIGURE 10.10 Alonso de la Vera Cruz, Speculum coniugiorum, Salamanca 1562: Andrea de Portonaris (Università di Roma, La Sapienza, IIc 55/v 8823), 522

On the other hand, the very general Relectio de matrimonio could not offer much help to Vera Cruz when he was finally able to access it. The first part of Vitoria's text, a very general definition of the essence and purpose of marriage, did not contain anything that other Salamanca masters (Soto, Azpilcueta, etc.) had not explained in a much more detailed manner in previous publications. With regard to the second part of De matrimonio, which addressed the various impediments to marriage and the dispensable character of the prohibitions found in Leviticus 18 - apart from marriage between parents and children, which was absolutely prohibited by natural law,$-{ }^{69}$ it is important to consider

69 Even if Vitoria, always extraordinarily attentive, was the first to note some of the implications that the pontifical dispensation granted to Henry viı to marry Catherine of Aragon 
that, by the 1560 s, Vera Cruz had at his disposal abundant literature written by other Salamanca masters as well as material occasioned by the English Schism to support these positions. Having somehow magnified the contribution of Vitoria on this issue, the historiography has tended to forget that he was not the only "intellectual" commissioned by Charles $\mathrm{v}$ to come up with juridical and theological reasons to oppose the annulment of his aunt's marriage. ${ }^{70}$

Even if it is important to downplay to some extent and explain within its proper historical context the influence of Vitoria on Vera Cruz, the rare mentions of Vitoria are interesting for many reasons. First of all, these mentions were always very respectful and laudatory. Vitoria was, in fact, the master who received the most beautiful "bouquets" within the treatise, being qualified as "nostris doctissimus olim magister meus Victoria" [my one-time teacherVitoria, the most learned of us all], "princeps Theologorum sui temporis" [the leader of theologians of his time], "gravis author, olim praeceptor meus" [a weighty authority, once my teacher], "unicus nostri temporis theologus olim magister meus Vitoria"71 [an unparalleled theologian of our time, once my teacher, Vitoria] ... Clearly, Vera Cruz would not have been bothered at all if someone

could have in the missionary context, which he briefly mentioned at the end of De matrimonio, "Manifestum est etiam quòd si talia matrimonia essent irrita iure naturali, non posset pontifex illa concedere, aut approbare, maximè cùm lex Moysi, non solùm apud Christianos, sed apud omnes mortales prorsus iam nullius sit virtutis, \& efficaciae. Quare si nobis iure naturali interdicerentur talia matrimonia, non releuaret ab hoc interdicto vel lex, vel dispensatio Moysi. Quare sine dubio concluditur, tale matrimonium non esse iure naturali prohibitum: vel si est, non ita tamen, ut si attentetur, factum dirimatur. Ex quo sequitur corollarium quòd omnes infideles contrahentes in gradibus ab ecclesia prohibitis, si non constet esse iure naturali prohibitum, vere contrahunt, \& est ratum matrimonium. Itaque si quis inter infideles duceret relictam fratris siue cum liberis, siue sine liberis defuncti, dubitandum non est, quin tale matrimonium esset ualidum, nec conuersi ad fidem indigent papae dispensatione, imò neque quacunque authoritate possent separari, scilicet cùm solo iure humano, quo infideles non tenentur, huiusmodi matrimonia sint interdicta", Vitoria, "De matrimonio", in Vitoria, Relectiones theologicae XII, Tomus I, 486-487.

70 As previously noted, even "outsiders" such as Sepúlveda, writing from Rome, tried to make a reputation for themselves and garner royal favour by weighing in on a dispute that was shaking the whole Christian world. A similarly large-scale involvement of "intellectuals" was observed in many other debates at the time: the American conquest, the annexations of Navarre and Portugal, the refutation of Luther, Calvin, and other reformers, ... Even on quite technical issues such as the fixing of the anti-meridian in the Pacific Ocean, various learned men were commissioned by the Castilian monarchy or offered their services to it, Duve, "Spatial Perceptions, Juridical Practices, and Early International Legal Thought around 1500".

71 Vera Cruz, Speculum coniugiorum (2009-13), Pars I, Art. 2, 84 (almost identical in Pars II, Art. 29, 436); Pars I, Art. 43, 552; Pars III, Art. 13, 248; Pars III, Art. 18, 298. 
had referred to him as a disciple of Francisco de Vitoria: it was something that he himself proudly highlighted from the first edition of his treatise. In one of the most interesting references to Vitoria, he even pointed to the emergence of a school of theologians consisting of his former students, in accordance with the guidelines established by their common master.

If one falsely promised [to marry] a girl whom he deflowered, if he is of equal or inferior condition to her, he is bound, under mortal sin, to take her as his wife. It is proved. He is obliged to offer compensation for the damages he inflicted and to keep his promise, since his condition is equal or inferior [to the one of the girl], but he cannot do otherwise, unless taking her as his wife. Therefore, he is obliged to take her as his wife. This conclusion is expressly supported by Navarrus (c. 16. num. 18. Manualis), Saint Antoninus (2. p. tit. 5. c. 6. 1) and Scotus. And the same holds true for Adrian vi (In quartum sententiarum) and the most expert among the theologians of his time and undoubtedly the principal, the master Vitoria (who was once my preceptor), together with some of his disciples, who are masters nowadays. ${ }^{72}$

This reference is important inasmuch as it demonstrates that, even if "it was only in the later 19th century that the term 'School of Salamanca' was coined", ${ }^{73}$ the concept should not be seen as a purely ideological construct. On the contrary, as the words of Vera Cruz and other students of Vitoria make clear, there was already a remarkable continuity between master and disciples in terms of thought and a common feeling of belonging emerging among Vitoria's disciples shortly after the master's death.

The Speculum coniugiorum is also a good example of the kind of presence that the early Vitoria - preceding the "printed Vitoria" - had in the writings of the first generation of students. Interestingly, even if not textually referenced,

72 "Si quis ficte promisit puellae quam corrupit, si sit ei aequalis, vel inferior conditione, tenetur sub mortali eam ducere. Probatur. Talis tenetur damnum resarcire, et promissum adimplere, cum sit aequa conditio, vel inferior: sed non potest aliter, nisi eam ducendo: ergo tenetur eam ducere. Istam conclusionem tenet expresse Navarro ca. 16. numer. 18. Manualis et S. Antoninus 2. p. tit. 5. ca. 6. 1. et Scotus. Idem Adrianus in 4. et sui temporis Theologorum consummatissimus, et facile princeps magister Vitoria olim praeceptor meus, et nonnulli alii subscribunt ex suis discipulis, qui nomen habent magistrorum", Vera Cruz, Speculum coniugiorum (1556), Pars III, Art. 19, 649. In the contemporary critical edition of Vera Cruz's Speculum (2013) that I have been following, Pars III, Art. $19,324$.

Duve, "The School of Salamanca: a case of global knowledge production". 
some of the Salamanca master's doctrines on marriage (in the example above, the obligation to marry a seduced virgin if the man was of equal or inferior condition to that of the seduced woman) and methodological principles were evoked as oral memories in the first edition of the Speculum, which, as previously noted, was printed before any of the writings of Vitoria. They derived from the memories of the young Vera Cruz, a student at the faculty of theology of the University of Salamanca from 1528 to 1532 . Given that he not only had the opportunity to attend the academic event where Vitoria delivered De matrimonio, hearing the relectio from the lips of the master in $1531,{ }^{74}$ but that he also had, in all likelihood, listened to Vitoria's most detailed analysis of matrimonial issues while commenting on Book IV of Peter Lombard's Sentences - dedicated, as is well known, to the sacraments - from 1529 to $1531,{ }^{75}$ Vera Cruz was able to bring to Michoacán the echo of Vitoria's ideas that were later reflected in the Speculum coniugiorum. This is, at least, the impression the reader is left with from a treatise that, referencing the different opinions of the master occasionally and in quite coherent and reliable way, did not seem to rely on any written support, either in printed or manuscript form.

As noted in the introduction of this chapter, the Speculum coniugiorum is not only important in terms of evaluating the influence that Vitoria and other contemporary masters had on missionary literature written in the Western Indies, but also that of the late-medieval Salamanca masters, referred to by recent historiography as the First School of Salamanca. ${ }^{76}$ Vera Cruz occasionally quoted some of these authors. Juan López de Palacios Rubios (1450-1524) and Juan López de Segovia (1440-1496) $)^{77}$ were, for example, referred to as learned juridical authorities who well represented the flexible tradition of Salamanca in relation to clandestine marriage. Moreover, one of the most

74 As well as the relectiones De potestate civili (1528), De homicidio (1529), and De potestate Ecclesiae prior (1532). Ramírez González, "Alonso de la Veracruz en la Universidad de Salamanca", 641.

75 Lanza and Toste, "The Sentences in Sixteenth-Century Iberian Scholasticism", 442-451.

$7^{6}$ Aspe Armella offers an account on this new literature in her chapter.

77 "Considerandum tamen est matrimonium contractum coram testibus sufficientibus etiam si sine sollemnitate, quae in iure positiva est fiat, clandestinum non dici proprie, ut notat Abbas ibi, in ca. Cum inhibitione. Et idem Ioannes Lupus Segoviensis in tractatu de matrimonio. Sic Sylvester in verbo, matrimonium 2. in fine. Et Palatios Rubius in c. Per vestras, notabilia 3. n. 21. Et Paludanus in 4. d. 28. q. 2. art. 3. conclusio 3, quamuis Bartolomaeus in l. fi. decr. de ritu nuptiarum, contrarium dicat. De quo Covarrubias in epitome 4. decretalium 2. p. c. 6. n. 10", Vera Cruz, Speculum coniugiorum (2009), Pars I, Art. 10, 200. Vera Cruz referred here to López de Segovia's Tractatus vere catholicus de matrimonio \& legitimatione and López de Palacios Rubios' Commentaria utilissima, insignisque repetitio rubricae \& capituli, pervestras. De donationibus intervirum \& uxorem. 
prominent "intellectuals" related to this First School of Salamanca, Alonso Fernández de Madrigal, "El Tostado" (1410?-1455) - or Abulensis, as Vera Cruz and his contemporaries referred to him -, was the most important authority in terms of Vera Cruz's own thinking on marriage. ${ }^{78}$

He was not only the second most quoted author in the Speculum, surpassed only by Thomas Aquinas - as Aspe mentions in her chapter -, but also the key authority for the resolution of the most problematic issues related to the marital customs of the infidels. ${ }^{79}$ A detailed analysis of the ideas Vera Cruz owed to El Tostado's biblical commentaries on the Gospel of Matthew or 1 Kings, in which Old Testament laws and traditional Jewish practices such as repudiation and polygamy were evaluated, would exceed the length of a book chapter. A representative passage demonstrating how, in some parts of the Speculum, El Tostado's writings were almost copied verbatim is the criticism both of them made of polyandry. Admitting the practice of polygamy in extraordinary cases (for example, in the hypothetical situation in which the human race was almost totally destroyed and an increase in the population was urgently needed), both of them coincided in the view that such a plurality of spouses could never or in any circumstances be allowed for women. El Tostado (in his repetitio De optima politia) and Vera Cruz gave the same reasons against polyandry: the collapse of household order (oikonomia) that would certainly happen in any society that tolerated polyandry and the harm to the republic that would be caused by such an unnatural regime in which paternity and inheritance would vanish into thin air. Interestingly, both of them also appealed to pseudo-medical classical literature that considered that the cohabitation of a single women with many men impeded procreation. ${ }^{80}$ The arguments and the order of exposition

78 Especially important for marriage were Fernández de Madrigal ("El Tostado”), Quinta pars Abulensis super Mattheum a decimo octavo usque ad vigesimumprimum capitulum inclusive, in Opera praeclarissima beati Alphonsi Tostati, Venezia, Gregorio de Gregori / Peter Liechtenstein, Tomus XI, 1529, Capitulum 19, Quaestiones 17-92, 51v-79v; Opus aureum beati Alphonsi Thostati episcopi Abulensis super quattuour libros Regum [...] Primus liber: qui in duos thomos divisus est. In primo habetur expositione a Capitulo primo usque ad quartumdecimum inclusive, in Opera praeclarissima beati Alphonsi Tostati, Tomus viI, 1528, 1 Regum, Capitulum 8, Quaestiones 24-236, fols. 59v-98; Divi Alphonsi episcopi Abulensis fructuosissima repetitio de optima politia in Opera praeclarissima beati Alphonsi Tostati, Tomus XIII, 1529.

79 For an example of the way in which Vera Cruz relied on Fernández de Madrigal ("El Tostado"), 1 Regum 8, q. 151, to underpin the pope's potestas to grant dispensations in relation to any transversal degree of consanguinity, see Speculum coniugiorum (2013), Pars II, Art. $27,396$.

8o "Secunda ratio est quia quod eadem mulier habeat multos viros repugnat intentioni naturae, natura enim invenit coitum: vel Dei voluntas statuit, atque humana ratio dictavit: ut 
followed by El Tostado and Vera Cruz are so close that it seems clear that either Vera Cruz rewrote El Tostado's arguments or both followed a common reference opposed to polyandry. The only important difference between the two approaches is that the sophisticated juridical and theological division between the first and second principles of natural law, which Vera Cruz inherited from Vitoria and Soto, is not found in El Tostado, who differentiated only between practices according to reason and those repugnant to it. ${ }^{81}$

Vera Cruz's continuous and very close references to El Tostado highlight the complex and not uniformly linear relationships that existed between the writings and ideas of different generations of Salamanca masters. With regard to the specific subject of marriage, it seems that El Tostado's influence was much more important than that of Vitoria, not only for Vera Cruz, but also for Soto ${ }^{82}$

per coitum fieret generatio, \& conservaretur natura specifica secundum successionem. Sed si eadem mulier multos viros haberet, impeditur ista intentio: quia numquam gignere posset. Mulier namque quae a pluribus cognoscitu in tempore vicino sibi concipere numquam potest. Sicut patet de meretricibus quae cum a plurimis cognoscantur: a nemine tamen concipiunt", Fernández de Madrigal ("El Tostado"), De optima politia, in Fernández de Madrigal ("El Tostado"), Opera praeclarissima, Tomus XIII, fol. 7v. "At si vna foemina plures habeat maritos, tollitur directe finis principalis, quem intendit natura, in matrimonio: ergo omnino est prohibitum per naturam: et sic contra prima praecepta iuris naturae, quod sic declaratur. Ingeniauit natura coitum, et Diuina voluntas sic declarauit, et dictauit ratio humana, vt per eum fiat generatio, et conseruatio speciei secundum successionem indiuiduorum: sed si mulier vna, plures habeat viros, impeditur generatio. Experientia quippe constat, mulierem quae a pluribus viris successiue, statim ab alio post alium cognoscitur, non concipere: sicut patet in meretricibus, quae publice expositae a pluribus cognoscuntur", Vera Cruz, Speculum coniugiorum, Pars II, Art. 17, 268.

81 "Sit sexta conclusio. Quamuis in eodem viro conueniens esse possit uxorum pluralitas: in eadem tamen femina toti rationi dissonant virorum diuersitas, id est, quod licet unus vir possit habere plures uxores: \& non repugnet hoc rationi: tamen una mulier non potest viros multos habere: quia valde repugnat rationi", Fernández de Madrigal ("El Tostado"), De optima politia, in Fernández de Madrigal ("El Tostado"), Opera praeclarissima, Tomus XIII, fol. 7v; "6. Conclusio. Licet verum sit in statu legis naturae et scriptae, licuisse tam fidelibus quam infidelibus plures habere uxores sine dispensatio proprie dicta, tamen in nullo tempore licuit mulieri plures habere maritos. Probatur. Quod est contra prima praecepta iuris naturae, nunquam licuit, neque licere potest: sed habere vnam vxorem, plures viros est directe contra prima praecepta iuris naturae, ergo nunquam licuit. Primum patet, vt superius dicebamus, quia talia repugnantia primis principijs, sunt de se mala, et nota ab omnibus vt talia, ob id apud omnes sunt reputata mala: quia ius naturale, quod est de primis principijs, et omne illud quod immediate, et directe repugnat eis, est idem apud omnes gentes", Vera Cruz, Speculum coniugiorum, Pars II, Art. 17, 266-268.

82 Also closely following El Tostado's refutation of polyandry and many other arguments while writing about marriage in his commentary on Lombard's Sentences. Soto, Commentariorum fratris Dominici Soto [...] in quartum Sententiarum, Salamanca, Andrea, de Portonaris, 156o, Distinctiones XXVI-XLII. 
and other contemporaries, which implies a kind of historical leap from the first half of the 15th century to the mid-16th century, which, as Aspe underlines in her contribution to this book, should be properly explained through further research into the emergence of the School of Salamanca.

\section{Building Bridges between Europe and the Indies: Native American Matrimonial Customs Studied against the Backdrop of the Christian Schism}

For various reasons, in the decades which preceded the writing of the Speculum coniugiorum, marriage became the fuse that set all of Europe alight and therefore gave rise to an unforeseen wave of debating and publishing on the topic. ${ }^{83}$ It is important to bear in mind some important European polemics of this period inasmuch as they all converged, in one way or another, in Vera Cruz's Speculum coniugiorum. On the one hand, even if the book was specifically conceived of as a guide to addressing very specific marital issues that affected infidels and neophytes in the New World, Vera Cruz could not resist the temptation to weigh in on the burning issues being discussed in Spain and the rest of Europe at this time. At times, he started his sections with a question arising from a concrete case found by missionaries in the Purépecha and Nahua regions, but he then tended to conclude his reasoning with the demonstration of a universal norm, valid for every one of the faithful or neophytes affected by or experiencing the same situation anywhere in the world. On the other hand, the Speculum coniugiorum also offered many examples which were reasoned in the opposite direction: starting with the affirmation of a clear and comprehensible principle of natural law or of a universal doctrine of the Church framed or consolidated perhaps in the recent debates with the schismatics -, Vera Cruz then proceeded to apply it to a very specific case that had come to the attention of the missionaries.

If we look at the Europe of the first half of the 16th century, we see that marriage was present in all the confessional debates that contributed to splitting the Christian orbis at this time. It is well known that juridical and theological issues concerning marriage were behind the English Schism (1534). While the English monarchy took the legitimacy of papal dispensation from impediments of affinity as an excuse to progressively call into question the whole pontifical potestas,

83 A detailed analysis of which can be found in Witte Jr., From Sacrament to Contract, and in Reynolds's more recent book, How Marriage Became one of the Sacraments. 
Luther, Calvin, and the Reformers of continental Europe attacked clerical celibacy and criticised the centrality that the Roman Church had given to the consent of the spouses as the essence of a legitimate and authentic marriage. ${ }^{84}$ As Reynolds has recently pointed out, not only Protestants and Catholics were divided by the many problematic questions on marriage. The positions of the advisors and conciliar fathers who participated in the discussions leading to the twelve canons and the decree of reformation approved by the XXIV session of the Council of Trent were far from unanimous on many important issues, ${ }^{85}$ something that Vera Cruz, as I previously mentioned, later used as a subterfuge against the canons on clandestine marriage which hindered the efforts of the missionaries in the rather informal context of the Indies. ${ }^{86}$

Apart from those fierce debates on marriage in the European context, Iberian theologians and jurists had to deal with some specific issues linked to the particular condition of the Iberian kingdoms as one of the last multiconfessional strongholds in Christian Europe. The challenge represented by the assimilation of thousands of Muslims and Jews who had converted to Christianity freely or by force in the late medieval and early modern periods without completely renouncing their ancestral marriage practices is another one of the historical elements that greatly influenced Iberian literature on marriage and gave it a distinctive character.

For example, while polygamy no longer seemed to be a relevant issue north of the Pyrenees from at least the late Middle Ages, being unanimously condemned as a practice "against natural law",87 many of the 16th-century

84 In the opinion of late Calvinist divulgators such as Innocent Gentillet, who bitterly denounced the theological focus on the spouses' will to marry, Catholicism was promoting clandestine marriages, disobedience against parents, economic and political chaos, and even the seizure of young girls coming from good and noble families, Gentillet, Le Bureau du Concile de Trente, 243-255.

85 Concilium Tridentinum: Diariorum, actorum, epistularum, tractatuum nova collectio, Freiburg im Brisgau, Societas Gorresiana, 1901-1961, 13 vols.

86 As Reynolds emphasised, the conciliar fathers and advisors, especially the Spaniards, were divided over clandestine marriage above all. While Pedro Guerrero, a disciple of Vitoria and student at the faculty of theology of Salamanca in the same period in which Vera Cruz did his studies, "championed" the reforms against "marriages contracted clandestinely or without parental consent" (Reynolds, How marriage became one of the sacraments, 952), other Spanish theologians and jurists trained at Salamanca were more loyal to the theological tradition and Vitoria's thinking, in which the consent of the spouses was considered as essentia and causa sufficiens of the marriage (Borobio, Unción de enfermos, orden y matrimonio en Francisco de Vitoria y Domingo de Soto, 129-130).

87 According to John Witte Jr., there was a "strong canonical position of the medieval and early modern Catholic Church that pronounced repeatedly that polygamy was against the 
Salamanca references to polygamy appear to be clearly distanced from this hypothetically unanimous position. ${ }^{88}$ Not only literature, but also documents relating to the institutional life of the Spanish Church and the main challenges it had to face in the conflictive southern regions of the country, which were then undergoing a process of Christianisation, make it clear that polygamy was still an important matter of practical concern ${ }^{89}$ and that Christian monogamy faced strong resistance from Muslims who had converted to Christianity. ${ }^{90}$

Marriage and divorce were also some of the most pressing issues in the recurrent polemics against marranos, converts from Judaism to Christianity whose adhesion and loyalty to the Christian faith was always regarded with suspicion. Popular and erudite anti-Semitic writings accused marranos of continuing the traditional practice of repudiation despite its explicit prohibition by Christ. ${ }^{91}$ The echo of this suspicion could still be heard even in the 18th century writings of later Dominican Thomist epitomists such as Vicente Ferrer

natural law properly understood, and that no earthly authority, whether pope or emperor, had power to grant a dispensation to practice it", The Western Case for Monogamy Over Polygamy, 169 .

88 Something that Witte recognises, identifying El Tostado and Tomás Sánchez - together with Gerson, Erasmus, Bellarmine, Mersenne, and Cajetan - as "exceptions" to the majority position that considered polygamy to be a crime against natural law. Taking into account that El Tostado's position on polygamy was received as valid by most of the theologians and jurists of the School of Salamanca and that Tomás Sánchez integrated most of these Salamanca writings into his Disputationes de sancti matrimonii sacramento (1602), one might wonder whether not only El Tostado and Sánchez, but also a significant part of Spanish authors in between, should be considered as having reservations about the unnatural character of polygamy. A case by case study still needs to be done.

89 For example, the priests who met at the Synod of Guadix (Andalusia) in 1554, organised by Bishop Martín de Ayala, another former student of theology at Salamanca and influential disciple of Vitoria, denounced the morisco neophytes of Granada, saying that they still conserved "las reliquias de su profana secta, la cual no hace más caso del santo matrimonio que si fuese un dañable concubinato, y así por leves causas pretenden apartarse y hacer divorcios por exquisitas maneras", Ayala, Synodo de la Diocesis de Guadix y de Baça, fol. 2 ov.

9o Taking into account the strong foothold of polygamic local customs, Bishop Martín de Ayala urged the priests under his jurisdiction to give special importance to monogamous marriage in their catechetical teachings and to monitor the proper implementation of Christian normativity. See Guardia Guardia, "Doctrina teológica del sínodo de Guadix de 1554", 34-35; Gallego y Burín, Vincent, and Gámir Sandoval, Los moriscos del reino de Granada según el sínodo de Guadix de 1554.

91 "He saith unto them, Moses because of the hardness of your hearts suffered you to put away your wives: but from the beginning it was not so", Matthew, 19:8. 
de Traiguera ${ }^{92}$ and Luis Vicente Mas, ${ }^{93}$ who still drew attention to the duty of priests and friars to ascertain whether the neophytes converted from Judaism in their dioceses still maintained the practice of repudiating their wives.

While the polemical references to the doctrines of Reformers and the echo of medieval debates with Jews and Muslims were elements that distinguished the whole early-modern Salamanca literature on marriage, a third contextual element differentiated what could be called the contributions of "colonial scholasticism"94 to those global debates. Confronted with the great diversity of marital and family customs and practices that Iberian missionaries encountered after their arrival in the New World, by the middle of 16th century, the period in which the Speculum coniugiorum was written, confusion prevailed on many important issues related to marriage. On some specific matters, "American" and "Asian" theologians, jurists, and missionaries had only conflicting probable opinions. Considering the Viceroyalty of New Spain, an examination of historical sources such as the decrees of the First Provincial Council of Mexico, ${ }^{95}$ held in Mexico City in 1555 - only one year before the first

$92 \quad$ Ferrer de Traiguera studied theology at the Monastery of San Esteban in Salamanca at the end of the 17th century and published the 18th century best-seller Suma moral para examen de curas $y$ confesores (1736). The attack on the legal excuse of the authorisation of repudiation in the Mosaic laws is in Tratado VII, Cap. IV, 169.

93 The Dominican Luis Vicente Mas, prima chair of St. Thomas Aquinas at the University of Valencia, continued to work on the text of Ferrer and published an extended and updated edition in 1770. In this edition, Mas reproduced a recent position of Benedict XIV which "prohibe à los Neofitos, que con ritus Rabinicos diessen libelo de repudio à su muger, ò èsta à su marido, que no quieren convertirse; y manda proceder contra ellos como Judaizantes", Suma moral para examen de curas y confessores (1770), Parte I, Tratado VII, Cap. IV, §. 4, 410. Both books were published many times in Spain and Mexico.

94 On this newly framed historiographical concept, see Hofmeister Pich and Culleton, "Introduction: The Challenge of Investigating Latin American Colonial Scholasticism".

95 See Chapter XXXII, against spiritual cognation and Chapter XXXVIII, against clandestine marriages as a practice contributing to unions "en grados prohibidos de consanguinidad, y afinidad, de que Dios es ofendido, y la República escandalizada”, Montúfar and Lorenzana, Concilios Provinciales primero, y segundo, 88-89 and 98-99. See also Chapters XXXIX-XLII, with special dispositions for the marriage of foreigners, those who married twice, etc., 100-105. Chapter LXIV appealed for a systematic registration of marriages among the indios in order to avoid any kind of "duda en alguna causa Matrimonial", 140. On their own, according to the instructions of Chapter LXXI, "Indios con título de mercaderes, y tratantes" who "andan vagabundos por muchos Pueblos" should be compelled to make a regular and sedentary marital life in order to avoid the frequent repudiations and second marriages, 147. Martínez-Cano demonstrated that many of these problematic situations persisted throughout the century and were still a matter of concern for the conciliar fathers of the Third Provincial Council of Mexico, who reiterated previous positions and offered new rules in Book 4, Titles I, § VI, VIII, X, XIII and Title II, § V. Martínez López-Cano, "Estudio introductorio, Tercer concilio provincial mexicano (1585)", 12. 
publication of the Speculum, and the letters addressed by missionaries to their superiors in Europe, who had the potestas to solve the most problematic and dubious cases, reflect a widespread sense of bewilderment.

Frequent disagreements among evangelisers could have pernicious effects, especially if the impossibility of reaching basic agreements persisted and missionaries contaminated the infidels and neophytes being instructed with their own differing and diverging conclusions. While a spirit of consensus about the need to draw clear red lines to root out clandestine cohabitations, polygamous practices, and parent-child relations prevailed among the secular and regular clergy, some of the most prudent and mindful missionaries insisted on the fact that many social and political issues could not be obviated. They considered that a quick, brutal, and unequal imposition of European-Christian matrimonial and familial normativity could offend the sensibilities of the natives, pushing them to feel themselves mistreated by tyrannical lords who arbitrarily interfered in their most intimate relationships and practices. It was, then, under the enormous pressure of these circumstances that Vera Cruz decided to lay down a detailed plan of action, aimed at guiding Mexican and American missionaries in the difficult task of translating Christian matrimonial normativity into the unforeseen contexts of the Western Indies.

These three important focal points of debate - European discussions between Catholics and Protestants, the long tradition of combatting Muslim polygamy and Jewish repudiation, and specific challenges to evangelisation in America and Asia - converged in the Speculum coniugiorum. As a result, while trying to characterise the process, in which Vera Cruz was engaged, of translating Western Christian normativity into Mexico, it is important to define it, first of all, as a translation of the European and Iberian polemics of the era to those American regions. Vera Cruz covered every burning controversy in the Europe of his time in his treatise because they were relevant to specific American issues and could be applied. For example, trying to support the sacramentality of the marriages contracted by the Indian infidels before and after the Spanish conquest as having a "sign of a sacred thing", ${ }^{66}$ Vera Cruz

96 For Vera Cruz, in a certain sense, those marriages could be considered as a sign of a sacred thing ("sacrae rei signum"), Speculum coniugiorum (2013), Pars II, Art. 35, "Utrum matrimonium inter infideles sit sacramentum", 482. In other words, the marriages contracted by the Indian infidels, even if not completely pleasing to God, were not offensive and unpleasant to Him and could, therefore, be somehow considered sacramental. "Et hoc modo capiendo, sacramentum matrimonii inter infideles gratiam confert: nam facit quod per istum actum conmixtionis maris et foeminae qui sic coniunguntur, non displiceant Deo, et non offendant Deum (..). Si tamen quis neget hanc dici gratiam, non contendo, quia quaestio est de nomine. Sed tamen dicitur sacramentum, ut sacrae rei signum est, 
related this problematic issue - was it, in fact, imaginable and admissible to speak of sacraments outside the Church? - to the doctrines of Luther and Calvin denying the general sacramental character of marriage. Interestingly enough, in the translation and localisation of this anti-Reformation polemic into the Mexican context, Vera Cruz clearly forced his argumentation, trying to make gains from the Catholic front in support of the sacramental nature of marriage to defend the sacramental and grace-conferring character of marriages contracted between the indigenous infidels. That was, in fact, one of the main goals of Vera Cruz's treatise, which underlined the intrinsic value of native marriages against the hard line supported by other missionaries who completely despised Nahua and Purépecha matrimonial rites and customs and who were in favour of compelling every converted infidels to remarry in facie Ecclesiae.

In this, Aperilius made a big mistake, and also the singularly fierce Luther (as well as in many other things), who says that marriage is not a sacrament. And previously the Armenians had fallen into this error that followed in our times Calvin, who said that no one had recognised marriage as a sacrament, until the time of Gregory. And in this they erred gravely, since, before Gregory, Ambrose, Augustine, and other classical authors asserted that marriage is a sacrament. And about this, see our Resolutiones Theologicae in quattuor libros sententiarum. Contrary to the above objection, I say that, just as the marriage of unbelievers is a sacrament, it also confers grace. ${ }^{97}$

The refutation of some Lutheran ideas was also important throughout the treatise to specify the character of infidel marriages, which, for Vera Cruz,

ut dicit Adrianus prima quaestione de matrimonio", Speculum coniugiorum (2013), Pars II, Art. 35, 488. In this theological position, Vera Cruz was quite isolated, as he himself recognised, mentioning the contrary opinion of the Franciscan Miguel de Medina (in De sacrorum hominum continentia, Venezia, Giordano Ziletti, 1569, Lib. v, Cap. 66, 485-487), an author with whom he usually agreed.

"In quo graviter errauit Aperillo, et singularis ferus Lutherus, sicut in aliis multis, negans matrimonium sacramentum esse. In quo errore fuerunt lapsi prius Armeni. Quem sequutus est nostris temporibus Caluinus, dicens nullum cognouisse matrimonium sacramentum esse, usque ad tempora Gregorii: in quo pessime errauit, cum ante Gregorium, Ambrosius, Augustinus, et alii classici viri asseruere matrimonium esse sacramentum. De quo in nostris Resolutionibus Theologicis in 4. ad obiectionem autem allatam dico, quod matrimonium infidelium eo modo quo est sacramentum, et gratiam confert", Vera Cruz, Speculum coniugiorum (2013), Pars II, Art. 35, 486. 
was legitimate but not equivalent to the exclusively Christian matrimonium ratum..$^{98}$ In problematic issues such as the contemporary validity of the prescriptions against consanguinity and affinity contained in Leviticus 18 (verse 24) and the pontifical potestas to grant dispensations for some degrees of consanguinity and affinity, Luther was also used as a scapegoat. ${ }^{99}$ His spectral appearance helped Vera Cruz to disqualify opinions that were not exclusively Lutheran, but relatively widespread among Catholic theologians and jurists who, against the criteria of Vera Cruz, considered the prohibitions mentioned in Leviticus 18 to still be in force. ${ }^{100}$

It was also when dealing with the topic of consanguinity that Vera Cruz translated the debates about the marriage of Henry viII and Catherine of Aragon into the American context. The general line of the Augustinian's argument on this issue was the following: the pope could legitimately grant Henry VIII and Catherine of Aragon a dispensation regarding the second degree of affinity laid out in the specific prohibition of Leviticus 18 - a legitimate dispensation on which only heretics might cast doubt - because Old Testament prohibitions were no longer in force as an essential part of divine law. Modern prohibitions concerning affinity were, in fact, derived from positive laws given by this or that pope and could therefore be abrogated or dispensed with according to the will of another high ecclesiastical authority.

Within his general aim of establishing flexible criteria for the delicate process of the cultural translation of Christian matrimonial normativity to the Indies, Vera Cruz also tried to take advantage of the very recent English Schism, another open wound that allowed him to make his own petitions

98 Given that, under certain circumstances, every non-Christian marriage could be dissolved after the conversion of one of the spouses to the Christian faith, a traditional position of the Church also attacked by Luther, "In quo errauit pestilentissimus Lutherus, qui adaequauit infidelium matrimonium, fidelium matrimonio, cum longe distent, ut patebit inferius. Quod bene probat Castro in suo de haeresi, libro 2. verbo nuptiae, haeresis 3", Vera Cruz, Speculum coniugiorum (2013), Pars II, Art. 1, 90.

99 "Et in hoc errauit Lutherus, qui dixit, gradus illos esse iuris Divini, et non posse Papa dispensare. Nec obstat dicere tales gradus esse de iure Divino veteri, quia (ut supra diximus) illud non obligat, neque lex, nec ius Divinum proprie dici potest: ad sensum quem modo loquimur de iure Divino obligante", Vera Cruz, Speculum coniugiorum (2013), Pars II, Art. 27,390 .

100 Vera Cruz was obliged to recognise that eminent medieval theologians such as Ricardus de Mediavilla, Alexander Hales, Saint Bonaventure, Hugh of Saint Victor, Francis of Mayrone, and Thomas Valdensis considered the prescriptions of Leviticus 18 to remain in force. That position was also defended by contemporaries of Vera Cruz, such as theologians Jean Viguier, John Major, and Sylvester Prierias and jurist Fernando de Loazes, Vera Cruz, Speculum coniugiorum (2013), Pars II, Art. 25, 364, 369; Pars II, Art. 27, 392. 
for extraordinary faculties of dispensation for the missionaries working in America and Asia. Taking things a step further, Vera Cruz insisted on the idea that not only positive laws against affinity, but also the ones concerning transversal consanguinity should fall under the same criteria. If Leviticus 18, as the debates about England had shown, was no longer in force and could not be considered a part of the current divine law, only marriage between parents and children - clearly contrary to natural and divine law - could fall under an absolute prohibition, ${ }^{101}$ such that other degrees of affinity and consanguinity could be permissible through dispensations from the pope if, in his view, a greater good or important and urgent reasons - just as the ones present in the American context - argued in favour of granting a dispensation. ${ }^{102}$

Driven by this practically oriented philosophy, the Speculum coniugiorum connected the Old World and the New, England and America, and Michoacán with Trent and Rome in many illuminating passages.

And that a dispensation could be made in that case of the king of England is proved by Clement vir against the Parisienses - see Castro, De lege poenali, lib. I, cap. 12. And given that this is a great concession and very necessary in foro conscientiae for the most serious cases, even after the Tridentine Council - since all the privileges of the religious orders in regard of those things which are opposed to the definitions of the Council have been confirmed motu proprio by the most holy Pope Pius $\mathrm{V}$, and considering also that this dispensation with regard to the internal forum is not eliminated by the Council -, the friars will be able to use it, especially in the New World, where certain things that in the Old World are not permitted and are not so necessary, are given and granted. ${ }^{103}$

101 "Item. Neque aliquis graduum, in linea transuersali est de iure Divino. Probatur. Non de iure Diuino Euangelico, quod obligat omnes: nam (ut nos in primera parte diximus, quando loquebamur de consanguinitate) nullus gradus a Christo fuit in euangelio sacro prohibitus, qui non fuisset de iure naturali: ob quod solum ibi reperitur gradus primus ascendentium, descendentium prohibitus, dicente Christo. Propter hanc relinquet homo patrem, et matrem, et adhaerebit uxori suae", Vera Cruz, Speculum coniugiorum (2013), Pars II, Art. 27, 388 .

102 "1. Conclusio. Summus Pontifex, in omni gradu tam affinitatis, quam consanguinitatis, in linea transuersali dispensare potest de plenitudine suae potestatis, licet id non expediat facere absque magna, et urgenti causa", Vera Cruz, Speculum coniugiorum (2013) Pars II, Art. 27,388 .

103 "Et quod potuit fieri dispensatio in casu illo regis Angliae, a Clemente 7. diffinitum est contra Parisienses, quam vide in Castro, de lege poenali, lib. 1. ca. 12. Haec est magna 
Assuming, therefore, that the validity of some of these marriages between relatives (by affinity or blood) would hardly be admitted in the Old World, ${ }^{104}$ Vera Cruz highlighted the specificity of the missionary context and pointed to "necessity" as the criterion justifying a special accommodation of some of the classical prescriptions in canon law concerning marriage. His aim was not to create a new canon law for the New World, but rather to exploit all the possibilities contemplated in traditional canon law to integrate American and Asian diversity within the bounds of what the legal and moral paradigms of his time could tolerate, while, at the same time, granting missionary agents room for manoeuvre in new and different contexts. ${ }^{105}$

\section{5 \\ From Opinions to Norms: Vera Cruz's Fight for the Transformation of His Doctrines into Pontifical Bulls and Reales Cédulas}

As Vera Cruz stated in the different editions of the Speculum, his, in many aspects, unorthodox positions had been warmly supported by the Roman Church since the Middle Ages. ${ }^{106}$ In the early decades of the 16th century,

concessio et quoad forum conscientiae in casibus grauissimis multum necessaria est post concilium Tridentinum, quia cum omnia religiosorum priuilegia sint confirmata a sanctissimo Papa Pio Quinto per propium motum in illis quae contradicunt diffinitionibus concilii, et haec dispensatio quoad animae forum non est ablata per concilium, poterunt religiosi ea uti maxime in nouo orbe, ubi specialiter data sunt et concessa quaedam quae in antique orbe non sunt permissa, neque sunt ita necessaria", Vera Cruz, Speculum coniugiorum (2013), Pars II, Art. 27, 404.

104 In Canon III, Session XXIV of the Council of Trent, it was determined that the Church could dispense with some of the degrees of affinity and consanguinity mentioned in Leviticus. Vera Cruz went much further in his Speculum than the council, denying any contemporary validity of the prescriptions of Leviticus and giving the pope the potestas to grant dispensations for almost any degree of affinity and consanguinity, with the exception of vertical consanguinity between parents and children.

105 This does not make Alonso de la Vera Cruz a kind of pioneer of multiculturalism, as some anachronistic interpretations of his writings have suggested. See Méndez Alonzo, "Poder civil y derechos naturales de los indios americanos según Fray Alonso de la Veracruz"; Beuchot, "Multiculturalismo republicano en Alonso de la Vera Cruz"; and Velasco Gómez, Republicanismo y multiculturalismo. In fact, it was only because of necessity, that is to say the practical impossibility of rapidly imposing a Christian normative framework, that a certain degree of flexibility and special adaptations had to be contemplated.

106 Popes such as Alexander IV and Boniface VIII had granted the Augustinian order the same missionary privileges held by the Dominicans and Franciscans. An overview of these historical privileges and a brief perspective of their translation into early modern America can be found in Campo del Pozo, Los Agustinos en la evangelización de Venezuela, 199-205. 
popes such as Leo X (1513-1521), Adrian VI (1522-1523), and Paul III (15341549) had confirmed and even augmented the late medieval privileges of the Augustinians and other mendicant orders with many bulls specifically addressing the New World missionaries. ${ }^{107}$ Concerning marriage, those privileges allowed friars to administer the sacrament to neophytes, intervene in matrimonial cases, and grant dispensations to various impediments. ${ }^{108}$

The prevailing situation of the first half of the 16th century, characterised by the great room for manoeuvre given to missionaries in still little-known areas, became more complicated just after the writing and publication of the first edition of the Speculum coniugiorum. According to Chapter 11 of the Decretum de regularibus et monialibus approved by the Council of Trent, monasteries "in charge of the pastoral care of secular persons" were put under the authority of the local bishop. With regard to the administration of the sacraments, Trent also subjected the friars to the "jurisdiction, visitation, and correction of the bishop". An explicit revocation of the missionary privileges that had been granted to the friars by Pius IV in 1564 made their situation even more difficult. ${ }^{109}$

Within this adverse context, Alonso de la Vera Cruz - who, after 26 years in Mexico, was obliged to return to Spain in 1562 in order to defend himself against the denunciations that the archbishop of Mexico, Alonso de Montúfar, had submitted against him to the Spanish Inquisition ${ }^{110}$ - had to engage in additional rows with the secular clergy for the renewal and confirmation of previous pontifical privileges and for the autonomy of the Augustinian

107 Leo x, Bulls Superioribus diebus (1517), Dudum per nos (1519), Alias felicis (1521); Adrian VI, Bull Exponi nobis, better known as the Omnimoda, see Campo del Pozo, Los Agustinos en la evangelización de Venezuela, 202-203. Vera Cruz mentioned those privileges in different parts of his Speculum, claiming the right of missionaries to intervene in marriage cases "Quod patet per bullam expressam concessam ordini praedicatorum per Nicolaum 4. ut illi qui ad terras infidelium transirent, possint iudicare de causis matrimonialibus. Idem per Adrianum 6. et Paulum 3. ut in ipsis privilegiis est manifestum", Vera Cruz, Speculum coniugiorum (2013), Pars III, Art. 8, 156.

108 The privileges made it clear that friars could at least grant dispensations for impediments related to affinity, "Et hoc confirmatur expressa concessione Leonis 10. qui dedit fratribus ordinis sancti Augustini quod cum his, qui in primo affinitatis gradu scienter, aut ignoranter contraxerunt, modo notorium id non fuerit, neque iudicium productum, dispensare valeant ut de nouo contrahant, et eodem item contracto matrimonio remaneant, prole quin etiam legitima", Vera Cruz, Speculum coniugiorum (2013), Pars II, Art. 27, 404.

109 Pius IV, Bull In Principis Apostolorum sede (1564), see Campo del Pozo, Los Agustinos en la evangelización de Venezuela, 205.

110 Lazcano, Fray Alonso de Veracruz, 68-71. The denunciations of Alonso de Montúfar (1558) and his secretary, Gonzalo de Alarcón (undated), can be found in the Archivo Histórico Nacional (Spain), (AHN), Inquisición, 4427, n. 5; AHN, Inquisición, 4442, n. 41. 
province in Mexico, which was still dependent on that of Castile. ${ }^{111}$ Vera Cruz obtained some provisory but important victories in a long series of legal disputes. The patient but tireless pressure Vera Cruz put on the court of Philip II and the Roman curia, which continued until 1568, resulted in an apostolic brief (Exponi nobis nuper in March 1567) revoking previous abolitions of the historical privileges of the orders. Vera Cruz not only obtained this revocation from Pius v but also a later and even clearer bull (Etsi Mendicantes Ordines in June 1567) in which the pope, referring explicitly to the American and Asian missions, augmented even previous motu-proprio privileges. A supplementary and extraordinary potestas to grant dispensations from impediments of affinity and consanguinity, in line with Vera Cruz's arguments, was given to the friars in 1571, ${ }^{112}$ the year in which Pius V also conceded the right to marry their current wife to the neophytes of the New World, even if she was not their first one. ${ }^{113}$ Additionally, royal authority firmly supported the pontifical decisions with two reales cédulas, dictated by Philip II in September of 1567 and January of 1568. The president and oidores of the Real Audiencia of Mexico were ordered to promulgate and enforce the bulls issued by Pius $\mathrm{v}$, removing any obstacles the bishops could find to impede the friars who "administren en los pueblos de los indios de esa tierra los santos sacramentos, como lo solían hacer antes del concilio tridentino, con licencia de sus prelados, y sin otra licencia".114

For Vera Cruz, the main specialist on marriage in the New World, the pontifical and royal support also represented a provisional triumph of his doctrines favouring the flexible translation of Christian normativity regarding marriage into the American continent. The privileges for which he had fought so hard gave friars, more than anything, a certain window of time and experience in order to make Indians perfect Christians in the medium term.

111 The conflicting issues in these disputes were many. Two interesting general perspectives can be found in Rubial García, "Fray Alonso de la Veracruz, agustino" and González González, "Fray Alonso de la Veracruz, contra las reformas tridentinas".

112 Vera Cruz included the matrimonial privileges granted by Pius v in 1571 in his Compendium privilegiorum. They also appeared in the index of its epitomized version, elaborated by the Dominican Alonso de Noreña under the title Compilatio privilegiorum, fol. 84v. The manuscripts of both, ready to print, can be found in the Biblioteca Real de El Escorial, Madrid (Spain), (BRE), MS III-K-6.

113 Bull Romani Pontifices, 2 August 1571. See Lisi, El Tercer Concilio Limense y la aculturación de los indígenas sudamericanos, 251.

114 "Cédula del rey Nuestro Señor para que se haga guardar un breve de Pío v, a pedimento de S. M. concedido a los religiosos de las Indias", in Mendieta, Historia eclesiástica indiana, 483. Mendieta's Historia, written at the end of the 16th century (but first published only in 1870) also reproduced the brief Exponi nobis super and a later cédula real of January 1568, $483-487$. 
Given the importance of pontifical privileges for the administration of the sacraments, Vera Cruz's aim was to accompany his Speculum coniugiorum, from its first edition, with a compendium aliquorum privilegiorum granted by popes to missionaries in the New World. The title page of the 1556 edition included a reference to this (figure 10.1). ${ }^{115}$ It is unknown exactly why this initial intention was not or could not ultimately be accomplished by Vera Cruz. According to Juan de Grijalva, the first chronicler of the Augustinian order in Mexico, the "forçossa contradiccion que avia de tener" that compendium, ${ }^{116}$ was the reason why Vera Cruz prudently refrained from his initial intent. In any case, as the same Grijalva stated, Vera Cruz's compilation of privileges would have circulated widely among the friars of various orders in manuscript form from the mid-1550s. ${ }^{117}$ Modern archival findings have confirmed this, locating different copies of the compendium ${ }^{118}$ and demonstrating that it was only a section of a wider Apologia pro religiosis trium ordinum mendicantium, habitantibus in Nova Hispania et pro indigenis ${ }^{119}$ [Defence of the religious of the three mendicant orders that there are in New Spain and of indigenous peoples] which Vera Cruz worked on throughout his life, waiting for an appropriate moment to publish it, although that moment apparently never arrived.

Even after the clear victories obtained in the period 1567-1571, Vera Cruz was not allowed to publish his many manuscripts on mendicant privileges. He did, however, obtain permission to print the bulls and cédulas reales for

115 "Accessit in fine compendium breue aliquorum priuilegiorum, praecipue concessorum ministris sancti evangelii huius noui orbis", Vera Cruz, Speculum coniugiorum (1556), Title page.

116 Grijalva, Crónica de la orden de N. P. S. Agustín en las provincias de Nueva España, fol. $188 \mathrm{v}-199 \mathrm{r}$.

117 "Escriviò un Compendio de todos los privilegios concedidos à las Religiones, y los concedidos à la conversión de los Indios, que fue la obra mas util que à avido para esta tierra: no la imprimió, por la forçossa contradicción que avia de tener, pero son muy pocos los Religiosos que no los tienen manu escriptos. Enfin el fue el que interpretò y defendiò las doctrinas, que particularmente corren en el que llamamos nuevo mundo", Grijalva, Crónica de la orden de N. P. S. Agustín en las provincias de Nueva España, fol. 188v.

118 JCBL, MS Codex Lat 4; Biblioteca Pública del Estado, Guadalajara, Jalisco (Mexico), (вPEG), мS 142. See González González, "Fray Alonso de la Veracruz, contra las reformas tridentinas" and Sánchez Gázquez, "Fray Alonso de la Veracruz (1507-1584) y su Compendium privilegiorum: estado de la cuestión manuscrita".

119 Vera Cruz, Alonso de la, Apologia pro religiosis trium ordinum mendicantium, habitantibus in Nova Hispania, in partibus Indiarum maris Oceani et pro indigenis, BRE, MS III-K-6: De decimis (fols. 1r-78v); Compilatio privilegiorum (fols. 83r-147r); Compendium privilegiorum (fols. 155r-175r); Expositio privilegii Leonis decimi (fols. 176r-234r); Declaratio seu expositio Clementinae (fols. 269r-345r). See Campo del Pozo, "Fray Alonso de Veracruz y el compendio de todos los privilegios de los religiosos". 
which he himself had fought so hard. The apostolic brief of March 1567 and a brief table of the privileges granted by Pius V was quickly published in Spain ${ }^{120}$ and Mexico. ${ }^{121}$ Those privileges were then republished in the "Old"122 and New Spain (figure 10.11) 123 $^{12}$ together with the second bull dictated by the pope motu proprio and the real cédula of September 1567. Vera Cruz republished those materials again, together with earlier bulls of Leo $\mathrm{x}$ and Adrian VI and the real cédula of January 1568, in the second part of the Appendix ad Speculum coniugiorum (Alcalá, 1571). ${ }^{124}$

A deep and exhaustive study of this part of the juridical production of Alonso de la Vera Cruz has yet to be undertaken. Given its extent, it would be a herculean task, and it is something far beyond the scope of this chapter. What I wanted to highlight with this excursus about such a juridical and printing imbroglio is that, different from most of the theological literature written in the Salamanca University context, the Speculum coniugiorium was far from being a mere piece of erudition written in a state of ataraxia and reflection. It clearly goes beyond the kind of dialogue between classical authorities and masters that could be found in the most theoretical commentaries on Aquinas or Peter Lombard.

In close connection with the practical American missionary context in which the Speculum was written, it simultaneously appears to be a masterpiece of erudition and the perfect guide for friars dealing with matrimonial issues in the Western Indies, as well a weapon in the never-ending struggle between the secular and regular clergy. This was why Vera Cruz was so attentive in integrating recently published juridical and theological writings, such as those of Soto and Azpilcueta, and in carefully and skilfully including the related legislation in support of the points of view for which he himself had fiercely fought during his long, enforced stay in Spain (1562-1572). Looking closely at the different

120 [Vera Cruz], Letras apostolicas de la bulla de la confirmacion y nueua concession, de los preuilegios y gracias concedidas, por los summos pontifices a todas y cada una de las ordenes de los mendicantes; con ciertas declaraciones, decretos, vedamientos, e inhibiciones de nuestro muy sancto padre Papa Pio quinto, [Alcalá?], [s.n.], [1567].

121 [Vera Cruz], Tabula privilegiorum, quae sanctissimus Papa pius quintus, concessit fratribus mendicantibus: in bulla confirmationis, \& novae concessionis privilegiorum, ordinum mendicantium, México, Antonio de Espinosa, 1567.

122 [Vera Cruz], Confirmatio et nova concessio privilegiorum omnium ordinum mendicantium, Sevilla, Juan Gutiérrez, 1568.

123 [Vera Cruz], Bulla confirmationis et novae concessionis privilegiorum omnium ordinum Mendicantium. Cum certis declarationibus decretis et Inhibitionibus. S. D. N. D. Pii Papae V. Motu proprio, México, Antonio de Espinosa, 1568.

124 Vera Cruz, Appendix ad Speculum coniugiorum [...]. Iuxta diffinita in sacro universali Concilio Tridentino, circa matrimonia clandestina, Alcalá, Pedro Cosin, 1571, 132-144. 


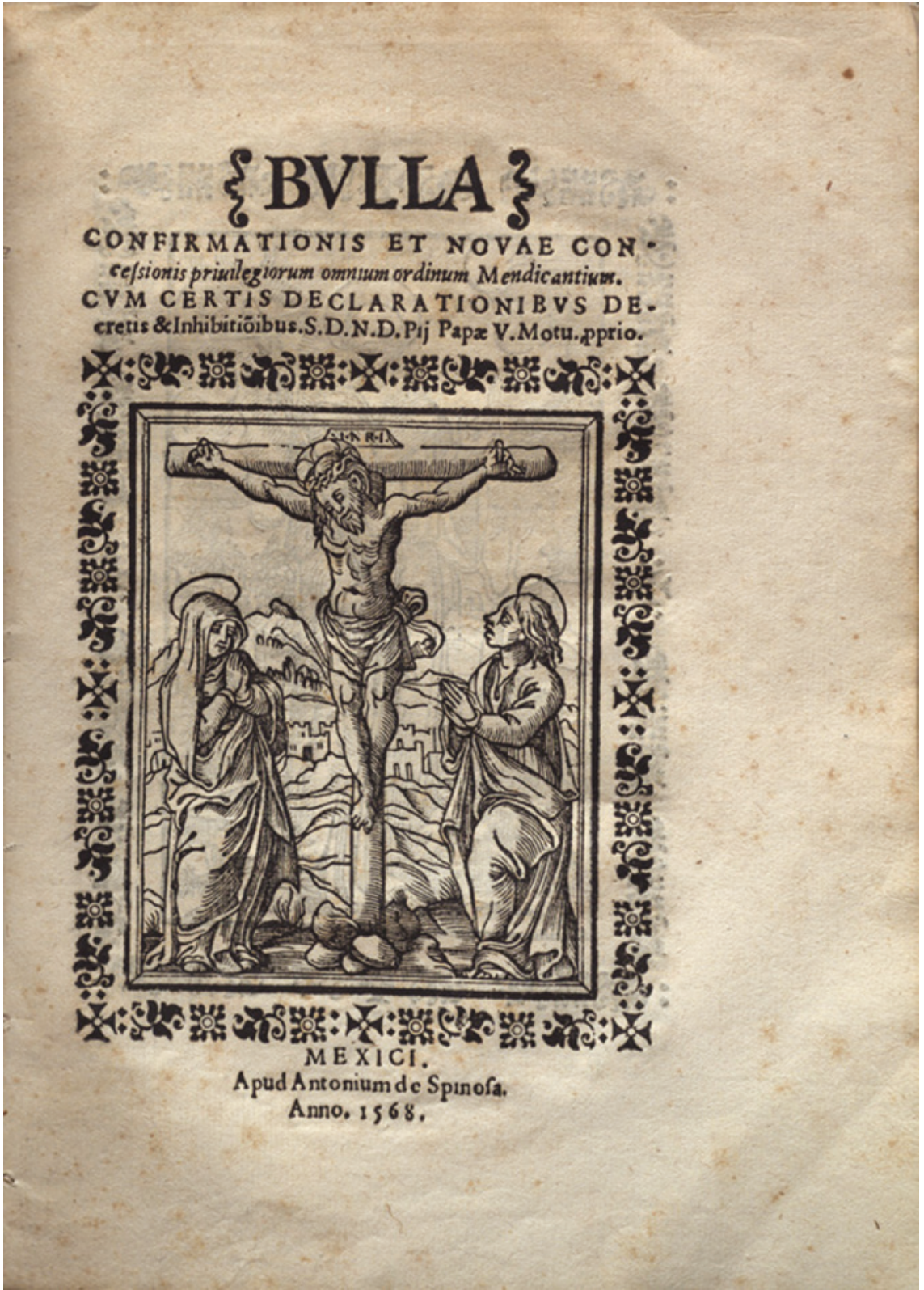

FIGURE 10.11 [Alonso de la Vera Cruz], Bulla confirmationis et novae concessionis privilegiorum omnium ordinum Mendicantium, México 1568: Antonio de Espinosa (Benemérita Universidad Autónoma de Puebla, Biblioteca Histórica José María Lafragua, 7138_03-41010303), title page 
editions of the Speculum, one can see that every new edition was strengthened by the approval of new canon and civil laws, and that the ones obtained in situ after his direct involvement played a very important role in its third and final edition. ${ }^{125}$

To conclude, the different elements mentioned above demonstrate that the Speculum coniugiorum corresponds well to the kind of "deliberations on practical issues" that, as Duve states in the introductory chapter, made Salamanca "famous". Inasmuch as its main aim was not to become the most systematic presentation of all the erudite nuances that could appear in matrimonial cases or that had been addressed in previous treatises, but rather to respond "to specific and concrete individual questions" - even urgent ones, one could say, as a complement to Duve's remarks - Vera Cruz well represents the two-fold practical and theoretical dimensions that distinguished the life and works of other key figures of the School of Salamanca (Matías de Paz, Domingo de Soto, Francisco de Vitoria, Bartolomé de Las Casas, Melchor Cano, etc.).

In this sense, it is important to take into account that Vera Cruz did not limit himself to proposing solutions for some difficult matrimonial cases to his students, expecting that his opinions would reach, through the mere circulation of his book, the political centres and prominent individuals who had the potestas that enabled them to make binding decisions regarding the most problematic of these cases. Instead, he personally travelled to the places where normative knowledge and legal provisions were produced in the Spain of that time: Salamanca and Madrid. He revised and republished his book on marriage in those strategic cities and fought for the transformation of his doctrines into bulls and reales cédulas. Consequently, in Vera Cruz's life and work, there converged different practical dimensions: the resolution of cases in foro interno et externo as confessor and de facto ecclesiastical judge of the doctrinas

125 "In diebus nostris pro religiosis in nouo orbe, S. S. Papa noster Pius quintus ad petitionem potentissimi regis Hispaniarum Philippi secondi, concessit omnia qua ante Concilium Tridentinum religiosis concessa erant, ad ministerium conuersorum, et conuertendorum ex Indis. Et per Leonem 10. Et Adrianum 6. Sub istis verbis in quibus dioecesanibus interdicit Pontifex, ut in loco ubi sunt monasteria, vel in loco ubi de licentia praelati manent religiosi, tam in signatis locis, quam in signandis, nihil innouent: sed de licentia suorum praelatorum, sine alicuius alterius licentia, possint sacramenta ministrare sicut ante. Et ad executionem huius diplomatis rex suas dedit litteras. Quibus omnibus suis ministris iniungit publice hoc indultum in nouo orbe denunciare, ut neophyte ad religiosos recurrant in nouo orbe ut olim ante Concilium Tridentinum, ut supra diximus, quod privilegium ad literam in fine in appendice appositum est", Vera Cruz, Speculum coniugiorum, Pars III, art. 8, 156 . 
where he lived with other Augustinian friars; ${ }^{126}$ the guidance he offered to students and fellow friars in his pragmatically oriented writings; and the decisive influence that, as procurator of his order, Vera Cruz had on different legislative processes taking place in Madrid and Rome. In light of what has been said, and of what Cobo and Moutin show in their contributions to this book, it even seems that the kind of direct relationship between speculative knowledge and normative production that Duve highlights as an essential feature of the School of Salamanca's juridical and theological production, became even more radical during the first century of Iberian presence in the American and Asian contexts, when new regulatory frameworks were elaborated and implemented thanks to the substantial effort of many Salamanca-trained agents.

\section{Acknowledgements}

I am especially grateful to the director of the Museo Regional Michoacano, Dr Jaime Reyes Monrroy, who received me as soon as I arrived in Morelia and put me in touch with the staff of other archives and libraries, and to the museum staff member, Carlos Reyes Galván, who also offered me valuable support throughout my investigation. I would like to acknowledge the assistance of Dr Bernardo Enrique Pérez Álvarez, director of the Fondo Antiguo at the Universidad Michoacana, who was an invaluable help in coordinating my research, in addition to the entire team who worked with me for many long sessions at the library, which lasted until midnight at times: Abigail González, head of the Fondo Antiguo, and the library staff Yoali Béjar and Humberto Ledesma. I would also like to thank the director of the Museo y Archivo Histórico Casa de Morelos, Diana Alvarado Martínez, and the staff in charge of the preservation of the monasterial collection at the museo for their valuable assistance (Emelia Fernández Ramos; Sergio Monjaraz Martínez). I am grateful to Juan José Ocampo Zizumbo, director of the monastery of Cuitzeo, who was kind enough to accompany me to the monastery and introduce me to the library. Finally, I would like to thank the director of the INAH centre in

126 Rodolfo Aguirre has shown how friars exercised de facto the "potestates de orden y de jurisdicción" in the doctrinas under their supervision during the 16th century. According to Aguirre, "las limitaciones para el clero secular eran grandes, al punto que los religiosos ejercían en los hechos la justicia eclesiástica con el apoyo mismo de las autoridades civiles". It was only during the first half of the 18th century that the figure of the local ecclesiastical judge was consolidated in the Mexican context. See Aguirre Salvador, "El establecimiento de jueces eclesiásticos en las doctrinas de indios", 15-17. 
Michoacán, Jacinto Robles, for granting me all the permits needed to consult the Morelian books and documents that are mentioned in this chapter.

My travel and research trip in Michoacán were financed by the project RESISTANCE: Rebellion and Resistance in the Iberian Empires, 16 th-19th centuries $778076-\mathrm{H} 2 \mathrm{O} 2 \mathrm{O}-\mathrm{MSCA}-\mathrm{RISE}-2 \mathrm{O} 17$, which has received funding from the European Union's Horizon 2020 research and innovation programme under the Marie Skłodowska-Curie grant agreement number 778076 . The project is coordinated by Prof. Mafalda Soares da Cunha (University of Évora), Dr. Benedetta Albani (Team Leader of the project at the MPIeR), and Prof. Leopoldo LópezValencia (Team Leader at the Colegio de Michoacán), who offered me wonderful support during my stay. Andrés Iñigo Silva, Marco Toste, Natalie Cobo and Jesús de Prado Plumed gave me useful suggestions which helped me to correct some of the paleographic transcriptions reproduced in this chapter.

\section{Bibliography}

\section{Manuscripts}

Real cédula de 23-12-1572, Archivo General de Indias, Sevilla (AGI), Indiferente, 1968, L. 19, fol. 63 .

Real cédula de 19-01-1573, AG I, Indiferente, 1968, L. 19, fol. 71v.

Real cédula de 03-02-1573, AG I, Indiferente, 1968, L. 19, fol. $76 \mathrm{v}$.

Manuscript annotations to Alonso de la Vera Cruz, Speculum coniugiorum, Alcalá 1572: Juan Gracián, Museo Regional Michoacano (MRM), 56950-11.

Manuscript annotations to Alonso de la Vera Cruz, Speculum coniugiorum, Alcalá 1572: Juan Gracián, Museo de Sitio Casa de Morelos (MSCM), 56941-2.

Manuscript annotations to Alonso de la Vera Cruz, Speculum coniugiorum, Alcalá 1572: Juan Gracián, Fondo Antiguo de la Universidad Michoacana (FAUM), BPUM $\mathrm{BT}_{2} \mathrm{O} \mathrm{V}_{4} 1572$.

Alarcón, Gonzalo de, Denuncia de Alonso de la Vera Cruz ante la Inquisición, Archivo Histórico Nacional, Madrid (AHN), Inquisición, 4442, n. 41.

Montúfar, Alonso de, Denuncia de Alonso de la Vera Cruz ante la Inquisición, 31 de enero de 1558, AHN, Inquisición, 4427, n. 5 .

Vera Cruz, Alonso de la, Compendium generale privilegiorum pro novo orbe indico, John Carter Brown Library, Providence, Rhode Island (USA) (JCBL), MS Codex Lat 4.

Vera Cruz, Alonso de la, Compendium generale privilegiorum pro novo orbe indico, Biblioteca Pública del Estado, Guadalajara, Jalisco (Mехісо) (в PEG), МS 142.

Vera Cruz, Alonso de la, Apologia pro religiosis trium ordinum mendicantium, habitantibus in Nova Hispania, in partibus Indiarum maris Oceani et pro indigenis, Biblioteca Real de El Escorial, Madrid (Spain), (BRE), MS III-K-6. 
Vera Cruz, Alonso de la, Marginal annotations to Hadrianus Florentius, Quaestiones in quartum sententiarum praesertim circa Sacramenta, Paris 1518: heirs of Josse Bade, MRM, 56948-9.

\section{Printed Sources}

Ayala, Martín de, Synodo dela Diocesis de Guadix y de Baça, celebrado por el reuerendissimo señor don Martin de Ayala Obispo della, año de mill y quinientos y cincuenta y quatro, Alcalá 1556: Juan de Brocar.

Azpilcueta, Martín de, In tres de poenitentia distinctiones posteriores commentarii, Coimbra 1542: João Álvares and João de Barreira.

Azpilcueta, Martín de, Capitulo veynte y ocho de las Addiciones del Manual de Confessores, Valladolid 1570: Adrián Ghemart.

Basalenque, Historia de la Provincia de San Nicolás Tolentino de Michoacán, del Orden de N. P. S. Augustin, México 1673: Viuda de Bernardo Calderón.

Concilium Tridentinum: Diariorum, actorum, epistularum, tractatuum nova collectio, Freiburg im Brisgau 1901-1961: Societas Gorresiana, 13 vols.

Covarrubias, Diego de, In librum quartum Decretalium, De sponsalibus, Epitome, ac de Matrimonio, Salamanca 1545: Juan de Junta.

Curiel, Jerónimo, Tractatus de Concilio Generali \& de matrimonio regis Henrici octaui Anglici, \& de iubileo \& de vsuris \& vsurarijs \& eorum poenis, \& de cessatione a diuinis. $\&$ de pluralitate beneficiorum a iure prohibita, Salamanca 1546: Juan Picardo.

Escobar, Matías de, Americana Thebaida. Vitas Patrum de los religiosos ermitaños de Nuestro Padre San Agustín de la Provincia de San Nicolás de Tolentino de Michoacán, Morelia 2008.

Fernández de Madrigal ('El Tostado'), Alonso, Opera praeclarissima beati Alphonsi Tostati, Tomi VII, XI et XIII, Venezia 1528-1529: Gregorio de Gregori and Peter Liechtenstein.

Ferrer de Traiguera, Vicente, Suma moral para examen de curas y confessores: En que a la luz del Sol de las Escuelas de Santo Thomas se desvanecen los perniciosos extremos de laxedad, y rigor, y se manifiesta el apreciable medio, y Camino-real de la verdad, Valencia 1736: Joseph Thomas Lucas.

Ferrer de Traiguera, Vicente and Luis Vicente Mas, Suma moral para examen de curas y confessores: En que a la luz del Sol de las Escuelas de Santo Thomas se desvanecen los perniciosos extremos de laxedad, y rigor, y se manifiesta el apreciable medio, y Camino-real de la verdad, Valencia 1770: Francisco Burguete.

Fisher, John [episcopus Rossensis], De causa matrimonii Serenissimi Regis Angliae, Alcalá 1530: Miguel de Eguía.

Florentius, Hadrianus [Adrianus vi], Quaestiones in quartum sententiarum praesertim circa Sacramenta, Paris 1518: heirs of Josse Bade. 
Gentillet, Innocent, Le Bureau du Concile de Trente, auquel il est monstré qu'en plusieurs points iceluy concile est contraire aux anciens conciles et canons et à l'autorité du roy, Genève 1586: Ellie Viollier.

Grijalva, Juan de, Crónica de la orden de N. P. S. Agustín en las provincias de Nueva España: en quatro edades desde el año de 1533 hasta el de 1592, México 1624: [Juan Ruiz].

Loazes, Fernando de, Tractatus in causa matrimonii Henrici et Catherinae Angliae regum, Barcelona 1531: Carlos Amorós.

López de Palacios Rubios, Juan, Commentaria utilissima, insignisque repetitio rubricae \& capituli, per vestras. De donationibus inter virum \& uxorem, Lyon 1551: Godefroy and Marcel Bering.

López de Segovia, Juan, Tractatus vere catholicus de matrimonio \& legitimatione, in Tractatus universo iuris, De matrimonio, De dote, Venezia 1589: Societas Aquilae renovantis, fols. $39 \mathrm{v}-46 \mathrm{v}$.

Medina, Miguel de, De sacrorum hominum continentia, Venezia 1569: Giordano Ziletti.

Mendieta, Jerónimo de, Historia eclesiástica indiana, Barcelona 2018.

Montúfar, Alonso de, and Francisco Antonio Lorenzana (ed.), Concilios Provinciales primero, y segundo, celebrados en la muy noble, y muy leal ciudad de México, presidiendo el Illmo. Y Rmo. Señor D. F. Alonso de Montúfar, en los años de 1555, y 1565, México 1769: José Antonio de Hogal.

Ruiz de Virués, Alonso [Ulmetanus], De matrimonio regis Angliae, Tractatus, [s.l.] 1561: [s.n.].

Sepúlveda, Ginés de, De ratione dicendi testimonium in causis occultorum criminum, Valladolid 1538: [Nicolás Tierry].

Soto, Domingo de, Relectio de ratione tegendi et detegendi secretum, Salamanca 1541: Pedro de Castro.

Soto, Domingo de, De iustitia et iure, libri decem, Salamanca 1553: Andrea de Portonariis.

Soto, Domingo de, Commentariorum fratris Dominici Soto [...] in quartum Sententiarum, Salamanca 156o: Andrea de Portonaris.

Vera Cruz, Alonso de la, Speculum coniugiorum aeditum per R. P. F. Illephonsum a Vera Cruce Instituti Haeremitarum Sancti Augustini, artium ac sacrae Theologiae doctorem, cathedraeque primariae in inclyta Mexicana academia moderatorem, México 1556: Juan Pablo Bricense.

Vera Cruz, Alonso de la, Speculum coniugiorum ad modum R. P. F. Illephonsi a Vera Cruce Sacri ordinis Eremitarum S. Augustini, bonarum artium, ac sacrae Theologiae Magistri, moderatorisque; Cathedrae Primariae in Universitate Mexicana in partibus Indiarum maris Oceani: \&Provincialis eiusdem ordinis, \&observantiae. Nunc secundo opus elaboratum, \& ab authore a plurimis mendis, quibus scatebat, limatum, \& in multis locis auctum, Salamanca: 1562, Andrea de Portonaris. 
[Vera Cruz, Alonso de la], Letras apostolicas de la bulla de la confirmacion y nueua concession, de los preuilegios y gracias concedidas, por los summos pontifices a todas y cada una de las ordenes de los mendicantes; con ciertas declaraciones, decretos vedamientos, e inhibiciones de nuestro muy sancto padre Papa Pio quinto, [Alcalá?] [1567]: [s.n.].

[Vera Cruz, Alonso de la], Tabula privilegiorum, quae sanctissimus Papa pius quintus, concessit fratribus mendicantibus: in bulla confirmationis, \& novae, concessionis privilegiorum, ordinum mendicantium, México 1567: Antonio de Espinosa.

[Vera Cruz, Alonso de la], Confirmatio et nova concessio privilegiorum omnium ordinum mendicantium, Sevilla 1568: Juan Gutiérrez.

[Vera Cruz, Alonso de la], Bulla confirmationis et novae concessionis privilegiorum omnium ordinum Mendicantium. Cum certis declarationibus decretis et Inhibitionibus. S. D. N. D. Pii Papae V. Motu proprio, México 1568: Antonio de Espinosa.

Vera Cruz, Alonso de la, Appendix ad Speculum congiugiorum [...]. Iuxta diffinita in sacro universali Concilio Tridentino, circa matrimonia clandestina, Alcalá 1571: Pierre Cosin.

Vera Cruz, Alonso de la, Speculum coniugiorum admodum R. P.F. Illephonsia Vera Cruce [...] olim ibi Provincialis eiusdem ordinis, Nunc Prioris sancti Philippi apud Madritum Carpentanorum. Nunc tertio opus elaboratum, ab authore a plurimis mendis, quibus scatebat, limitatum, \& in multis locis auctum, \& iuxta diffinita \& declarata in sacro concilio Tridentino, per modum appendicis in fine scitu digna multa disputata, Alcalá 1572: Juan Gracián.

Vera Cruz, Alonso de la, Rev. Patris Fr. Alphonsi a Vera Cruce Hispani Ordinis Eremitarum S. Augustini. Et in primaria cathedra mexicana universitatis S.Theologiae Doctoris. Speculum coniugiorum cum appendice. Nunc primum in Italia Typis excusum, Milano 1599: Pacifico Pontio.

Vera Cruz, Alonso de la, Photographic reproduction and Index (Relectio de dominio infidelium), in Ernest Burrus (ed.), The writings of Alonso de la Vera Cruz, vol. III. Defense of the Indians: their rights II, Roma - St. Louis 1967.

Vera Cruz, Alonso de la, Sermons, Counsels, Letters and Reports, in Ernest Burrus (ed.), The Writings of Alonso de la Vera Cruz, vol. I. Spanish Writings I. Sermons, Counsels, Letters and Reports, Roma - St. Louis 1968.

Vera Cruz, Alonso de la, Letters and Reports, in Ernest Burrus (ed.), The Writings of Alonso de la Vera Cruz, vol. I. Spanish Writings II. Letters and Reports, Roma - St. Louis 1972.

Vera Cruz, Alonso de la, Speculum coniugiorum. Espejo de matrimonios. Primera parte: Matrimonio y familia, ed. Barp Fontana, Luciano, México 2009.

Vera Cruz, Alonso de la, Speculum coniugiorum. Espejo de matrimonios. Segunda parte: Matrimonio verdadero, ed. Barp Fontana, Luciano, México 2013. 
Vera Cruz, Alonso de la, Speculum coniugiorum. Espejo de matrimonios. Tercera parte: Matrimonio y divorcio, ed. Barp Fontana, Luciano, México 2013.

Vitoria, Francisco de, De matrimonio, in Francisco de Vitoria, Relectiones theologicae XII, Tomus I, Lyon 1557: Jacques Boyer, 426-487.

Vitoria, Francisco de, Relectiones undecim, Salamanca 1565: Juan de Canova.

\section{Literature}

Aguirre Salvador, Rodolfo, "El establecimiento de jueces eclesiásticos en las doctrinas de indios. El arzobispado de México en la primera mitad del siglo XVIII", in Historia crítica 36 (2008), 14-35.

Albani, Benedetta, "El matrimonio entre Roma y la Nueva España, historia y fuentes documentales (siglos XVI-XVII)", in Bravo Rubio, Berenice and Doris Bieñko de Peralta (eds.), De sendas, brechas y atajos. Contexto y crítica de las fuentes eclesiásticas, siglos XVI-XVIII, México 2008, 167-184.

Albani, Benedetta, Sposarsi nel Nuovo Mondo. Politica, dottrina e pratiche della concessione di dispense matrimoniali tra la Nuova Spagna e la Santa Sede (1585-1670), PhD in History, Roma 2009.

Aspe Armella, Virginia, "Análisis del placer y la sexualidad matrimonial en Alonso de la Veracruz”, in Euphyía. Revista de Filosofía 10:19 (2016), pp. 23-46.

Aznar Gil, Federico, La Introducción del Matrimonio Cristiano en Indias: Aportación Canónica (s. XVI), Lección inaugural del curso académico 1985-1986, Salamanca 1985. Aznar Gil, Federico, "El matrimonio en Indias: recepción de las Decretales X 4.19.7-8", in Revista de Estudios Histórico-Jurídicos 11 (1986), 13-42.

Aznar Gil, Federico, "La libertad de los indígenas para contraer matrimonio en las Indias (siglos XVI-XVII)", in Ius canonicum 32:64 (1992), 439-462.

Beristáin de Souza, José Mariano, Biblioteca hispano americana setentrional, Vol. III, 3 vols., Amecameca 1883 .

Beuchot, Mauricio, "Multiculturalismo republicano en Alonso de la Vera Cruz", in Revista de la Red Latinoamericana de Filosofía Medieval 2:1 (2015), 109-125.

Blair, Ann, Too much to Know. Managing Scholarly Information before the Modern Age, New Haven / London 2010.

Borobio, Dionisio, Federico Aznar Gil and Antonio García y García, Evangelización en América, Salamanca 1988.

Borobio, Dionisio, Evangelización y sacramentos en la Nueva España (s. XVI) según Jerónimo de Mendieta: lecciones de ayer para hoy, Murcia 1992.

Borobio, Dionisio, El sacramento de la penitencia en la Escuela de Salamanca: Francisco de Vitoria, Melchor Cano y Domingo Soto, Salamanca 2006.

Borobio, Dionisio, Sacramentos en general: bautismo y confirmación en la Escuela de Salamanca: Fco. Vitoria, Melchor Cano, Domingo Soto, Salamanca 2007. 
Borobio, Dionisio, Unción de enfermos, orden y matrimonio en Francisco de Vitoria y Domingo de Soto, Salamanca 2008.

Borobio, Dionisio, "Los sacramentos en Bartolomé de Ledesma (1525-1604). Un resumen comentado y actualizado", in Phase 58 (2018) 341-362.

Bragagnolo, Manuela, "Les voyages du droit du Portugal à Rome. Le 'Manual de confessores' de Martín de Azpilcueta (1492-1586) et ses traductions" in Max Planck Institute for European Legal History Research Paper Series 2018-13.

Bragagnolo, Manuela, "Managing Legal Knowledge in Early Modern Times: Martín de Azpilcueta's Manual for Confessors and the Phenomenon of Epitomisation", in Duve, Thomas and Otto Danwerth (eds.), Knowledge of the Pragmatici. Legal and Moral Theological Literature and the Formation of Early Modern Ibero-America, Leiden / Boston 2020, 187-242.

Campo del Pozo, Fernando, Los Agustinos en la evangelización de Venezuela, Caracas 1979. Campo del Pozo, Fernando, "Fray Alonso de Veracruz y el compendio de todos los privilegios de los religiosos”, in Revista Española de Derecho Canónico 73 (2016), 357-387.

Codoñer Merino, Carmen and Juan Signes Codoñer, "Una red de lecturas: las anotaciones marginales de Diego de Covarrubias", in Andrés Santos, Francisco Javier and Inmaculada Pérez Martín (eds.), Diego de Covarrubias y Leyva: el humanista y sus libros, Salamanca 2012, 151-180.

Dávila, Carmen Alicia, Catherine Ettinger and Salvador García Espinosa (eds.), Patrimonio nicolaita. Arquitectura, pintura y escultura de la Universidad Michoacana de San Nicolás de Hidalgo, Morelia 2015.

Duve, Thomas, "Spatial Perceptions, Juridical Practices, and Early International Legal Thought around 1500: From Tordesillas to Saragossa", in Kadelbach, Stefan, Thomas Kleinlein and David Roth-Isigkeit (eds.), System, Order, and International Law. The Early History of International Legal Thought from Machiavelli to Hegel, Oxford / New York 2017, 418-442.

Duve, Thomas, "Pragmatic Normative Literature and the Production of Normative Knowledge in the Early Modern Iberian Empires (16th-17th Centuries)", in Duve, Thomas and Otto Danwerth (eds.), Knowledge of the Pragmatici. Legal and Moral Theological Literature and the Formation of Early Modern Ibero-America, Leiden / Boston 2020, 1-39.

Fernández de Córdoba, Joaquín, “Michoacán: la historia y sus instrumentos”, in Historia Mexicana 2:1 (1952), 135-154.

Fernández de Córdoba, Joaquín, “Sumaria relación de las bibliotecas de Michoacán”, in Historia Mexicana 3:1 (1953), 134-156.

Gallego y Burín, Antonio, Bernard Vincent and Alfonso Gámir Sandoval, Los moriscos del reino de Granada según el sínodo de Guadix de 1554, Granada 1996.

Gómez Robledo, Antonio, "El problema de la conquista en Alonso de la Veracruz", in Historia Mexicana 23:3 (1974), 379-407. 
González González, Enrique and Víctor Gutiérrez Rodríguez, "Los catedráticos novohispanos y sus libros. Tres bibliotecas universitarias del siglo XVI", in Romano, Andrea (ed.), Dalla lectura all'e-learning, Bologna 2015, 83-102.

González González, Enrique, "Fray Alonso de la Veracruz, contra las reformas tridentinas: el Compendium privilegiorum pro novo orbe indico", in Martínez López-Cano, María del Pilar and Francisco Javier Cervantes Bello (eds.), Reformas y resistencias en la Iglesia novohispana, México / Puebla 2014, 77-110.

Guardia Guardia, Simón, “Doctrina teológica del sínodo de Guadix de 1554", in Boletín del Instituto de Estudios "Pedro Suárez": Estudios sobre las comarcas de Guadix, Baza y Huéscar 14 (2011), 9-38.

Hofmeister Pich, Roberto and Alfredo Santiago Culleton, "Introduction: The Challenge of Investigating Latin American Colonial Scholasticism”, in Hofmeister Pich, Roberto and Alfredo Santiago Culleton (eds.), Scholastica colonialis: Reception and Development of Baroque Scholasticism in Latin America, 16th-18th Centuries, Roma 2016, 1-34.

Lanza, Lidia and Marco Toste, "The Sentences in Sixteenth-Century Iberian Scholasticism", in Rosemann, Philipp (ed.), Mediaeval Commentaries on the Sentences of Peter Lombard, vol. 3, 3 vols., Brill 2015, 416-503.

Latasa, Pilar, "«If they remained as mere words»: Trent, Marriage, and Freedom in the Viceroyalty of Peru, Sixteenth to Eighteenth Centuries", in The Americas: A Quarterly Review of Latin American History 73:1 (2016), 13-38.

Latasa, Pilar, "Tridentine Marriage Ritual in Sixteenth- to Eighteenth-Century Peru: From Global Procedures to American Idiosyncrasies", in Rechtsgeschichte Legal History Rg 27 (2019), 105-121.

Latasa, Pilar, "Matrimonios clandestinos y matrimonios secretos (DCH)", in Max Planck Institute for European Legal History Research Paper Series 2019-11.

Lazcano, Rafael, Fray Alonso de Veracruz (1507-1584), misionero del saber y protector de indios, Madrid 2007.

Lilao Franca, "A la búsqueda de los libros de Diego de Covarrubias", in Andrés Santos, Francisco Javier and Inmaculada Pérez Martín (eds.), Diego de Covarrubias y Leyva: el humanista y sus libros, Salamanca 2012, 133-150.

Lisi, Francesco, El Tercer Concilio Limense y la aculturación de indígenas sudamericanos, Salamanca 1990.

Martínez López-Cano, María del Pilar, "Estudio introductorio, Tercer concilio provincial mexicano (1585)", in Concilios provinciales mexicanos. Época colonial, México $2015,1-27$.

Méndez Alonzo, Manuel, "Poder civil y derechos naturales de los indios americanos según Fray Alonso de la Veracruz", in Ideas y valores $15^{1}$ (2013), 195-213.

Pavón Romero, Armando and Clara Inés Ramírez González, "La carrera universitaria en el siglo XVI. El acceso de los estudiantes a las cátedras", in Luna Díaz, Lorenzo Mario (ed.), Los Estudiantes: trabajos de historia y sociología, México 1989, 56-10o. 
Pavón Romero, Armando, "La Universidad de México en tiempos de fray Alonso de la Veracruz”, in Velasco Gómez, Ambrosio (ed.), Alonso de la Veracruz: universitario, humanista, científico y republicano, México 2009, 47-62.

Quijano Velasco, Francisco, "Las fuentes del pensamiento político de Alonso de la Veracruz. Autoridades en el tratado De dominio infidelium et iusto bello", in Libro Anual del ISEE 14 (2012), 13-42.

Ramírez González, Clara Inés, "Fray Pedro de la Peña y la fundación de la Real Universidad", in Pavón Romero, Armando and Clara Inés Ramírez González (eds.), El catedrático novohispano: oficio y burocracia en el siglo XVI, México 1993, 15-37.

Ramírez González, Clara Inés, Grupos de poder clerical en las Universidades hispánicas, Vol. II. Los regulares en Salamanca y México durante el siglo XVI, 2 vols., México 2002. Ramírez González, Clara Inés, "Alonso de la Veracruz en la Universidad de Salamanca: entre el tomismo de Vitoria y el nominalismo de Martínez Silíceo", in Salmanticenses 54 (2007), 635-652.

Reynolds, Philip, How Marriage Became of the Sacraments: The Sacramental Theology of Marriage from its Medieval Origins to the Council of Trent, Cambridge 2016.

Rípodas Ardanaz, Daisy, El matrimonio en Indias: realidad social y regulación jurídica, Buenos Aires 1977.

Rubial García, Antonio, "Fray Alonso de la Veracruz, agustino. Individualidad y corporativismo en la Nueva España del siglo XVI", in Ponce Hernández, Carolina (ed.), Innovación y tradición en fray Alonso de la Veracruz, México 2007, 79-101.

Sánchez Gázquez, Joaquín, "Fray Alonso de la Veracruz (1507-1584) y su Compendium privilegiorum: estado de la cuestión manuscrita", in Evprhrosyne. Revista de filología clásica 45 (2017), 367-380.

Torchia Estrada, Juan Carlos, "La querella de la escolástica hispanoamericana: Crisis, polémica y normalización”, in Cuyo. Anuario de Filosofía Argentina y Americana 24 (2007), 35-77.

Velasco Gómez, Ambrosio, Republicanismo y multiculturalismo, México 2006.

Witte Jr., John, From Sacrament to Contract. Marriage, Religion, and Law in the Western Tradition (second ed.), Louisville (KY) 2012.

Witte Jr., John, The Western Case for Monogamy Over Polygamy, Cambridge 2015.

Zaballa Beascoechea, Ana de, "Matrimonio (DCH)", in Max Planck Institute for European Legal History Research Paper Series No. 2018-15.

Zaballa Beascoechea, Ana de, "El matrimonio indígena antes y después de Trento. Del matrimonio prehispánico al matrimonio cristiano en la Nueva España", in Rechtsgeschichte - Legal History Rg 27 (2019), 90-104. 